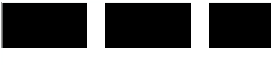

THE WILLIAM DAVIDSON INSTITUTE AT THE UNIVERSITY OF MICHIGAN BUSINESS SCHOOL

\section{Equilibrium Real Exchange Rates in Central Europe's Transition Economies: Knocking on Heaven's Door}

\author{
By: Balázs Égert
}

William Davidson Working Paper Number 480

July 2002 


\title{
Equilibrium Real Exchange Rates in Central Europe's Transition Economies : Knocking on Heaven's Door
}

\author{
Balázs Égert ${ }^{1}$ \\ MODEM, University of Paris X - Nanterre
}

\begin{abstract}
The purpose of this paper is to study the equilibrium real exchange rate (ERER) in 5 CEE transition economies, namely the Czech Republic, Hungary, Poland, Slovakia and Slovenia. In so doing, we combine the fundamental equilibrium exchange rate (FEER) approach developed by Williamson (1994) with the behavioural equilibrium exchange rate (BEER) approach advocated by Clark and MacDonald (1998). Our analysis is based on the theoretical model proposed by Montiel (1999) which defines internal balance in terms of the relative price of nontradables and determines external balance in terms of net foreign assets. The empirical part of the paper consists in estimating a VAR-based 3-equation cointegration system. Long-term equilibrium values for relative prices are determined by using relative productivity and private consumption, while the current account, representing external balance, is linked to terms of trade and openness $([\mathrm{X}+\mathrm{M}] / \mathrm{GDP})$. In order to derive the ERER and then to compute total misalignment, we finally substitute the long-run values for external and internal balances in the simultaneously estimated cointegration relationship connecting the RER with relative prices and the current account. Results show that the gap between observed real exchange rate developments and the path of the equilibrium real exchange rate differs substantially among the 5 transition countries.
\end{abstract}

Keywords: Transition, Central and Eastern Europe, Real Exchange Rate, Cointegration

JEL Classification Codes: E31, F31, O11, P17

${ }^{1} 1$ MODEM, University of Paris X, 200, avenue de la République, 92001-Nanterre, France, Tel: ++33 1409759 75, Fax: ++33 1 409777 84, E-mail: Balazs.Egert@u-paris10.fr 


\section{Non-technical summary}

The goal of this paper is to investigate the equilibrium real exchange rate (ERER) in 5 CEE transition economies, namely the Czech Republic, Hungary, Poland, Slovakia and Slovenia. In so doing, the paper combines two approaches, namely that of the fundamental equilibrium exchange rate (FEER) developed by Williamson (1994) and that of the behavioural equilibrium exchange rate (BEER) proposed by Clark and MacDonald (1998). As a first step, we investigate real exchange rate developments in the aforementioned transition economies. Then, a brief overview of the existing literature is provided. With this as a background, we present a theoretical model of a small economy where internal balance is defined in terms of the relative price of nontradables and external balance is determined in terms of net foreign assets. The empirical part of the paper then tries to use these to definitions to estimate the equilibrium real exchange rate in a Johansentype cointegration framework. Long-term equilibrium values for relative prices are determined by using relative productivity and private consumption, while the current account, representing external balance, is linked to terms of trade and openness ([X+M]/GDP). In order to derive the ERER and then to compute total misalignment, we finally substitute the long-run values for external and internal balances in the simultaneously estimated cointegration relationship connecting the RER with relative prices and the current account. Results show that the gap between observed real exchange rate developments and the path of the equilibrium real exchange rate differs substantially among the 5 transition countries. The Czech Republic, Poland and Slovakia may have experienced an excessive appreciation of their real effective exchange rate whereas Hungary and Slovenia show little sign of overvaluation during the period under study. These results suggest the role flexible exchange rate regimes may play in exchange rate misalignments. 


\section{Introduction}

According to the extensive body of the literature dealing with the question of the equilibrium real exchange rate (ERER) in developed countries, the ERER is defined as the level of the real exchange rate when internal and external balances are achieved. Internal balance is usually determined in terms of the NAIRU while external balance refers to the sustainability of long-term capital flows. In practice, there are basically two approaches to estimate the ERER. On the one hand, Williamson (1994) and Bayoumi et al.(1994) employ large macroeconometric models in order to derive the fundamental and desired equilibrium exchange rates (FEER and DEER) ${ }^{2}$ respectively. On the other hand, using a relatively small theoretical model, Stein (1994) estimates the ERER what he calls the NATREX, by regressing a number of macroeconomic variables on the real exchange rate. Similarly, Clark and MacDonald employ time series cointegration techniques to connect the real exchange rate to fundamentals. In fact, they introduce the notion of the behavioural and the permanent equilibrium exchange rate (BEER and PEER): the ERER is obtained by substituting the long-term values of the fundamentals into the estimated cointegration vector $^{3}$.

When it comes to estimating the ERER for developing and emerging economies, it is common practice to use the single-equation approach for time series ${ }^{4}$ and for panel data including a large number of countries ${ }^{5}$. The same applies for studies investigating the equilibrium real exchange rate in Central and Eastern European transition countries. To our knowledge, the only paper, which uses the FEER approach, is that of Smidkova (1998). This is actually the main reason why we propose to estimate the ERER for 5 transition economies, namely for the Czech Republic, Hungary, Poland, Slovakia and Slovenia by taking directly account of internal and external balances. The remainder of the paper is as follows: in Section II., we shortly discuss real exchange rate developments in the 5 transition countries under consideration. Subsequently, Section III gives an overview of the empirical literature and Section IV presents the theoretical framework. Section V deals with the empirically estimated system derived from the theoretical model. Section VI then describes the data we use for the estimation and Section VII overviews the econometrics employed. Section VIII analyses the results and attempt to assess the extent of a possible overvaluation of the 5 countries' effective real exchange rate over the period of 19912001. Finally, Section IX presents the concluding remarks.

\section{Real exchange rate developments in CEECs}

In this section, we briefly discuss macroeconomic developments in the 5 transition economies under investigation, keeping one eye on the real exchange rate. According to professional wisdom, Hungary experienced an excessive real effective appreciation of its national currency in the early stage of transition. Responsibility for this goes to the pegged exchange rate regime with discretionary adjustments against a currency basket composed of German mark and US dollar. As

\footnotetext{
${ }^{2}$ For recent studies employing the FEER approach to OECD countries, see e.g. Borowski et al (1998a, b), Borowski - Couharde (2000a, b), Joly et al. (1999) and Couharde - Mazier (2000), IMF(2000).

${ }^{3}$ See e.g. Feyzioglu (1997), Alberola et al. (1999), Maurin (2000), Clostermann - Schnatz (2000), Maeso-Fernandez et al (2001).

${ }^{4}$ Cf. Edwards (1994), Elbadawi (1994), Baffes et al. (1999), Mongardini (1998), Sundarajan et al. (1999) and Lim (2000). An exception is Paiva (2001) who estimates the FEER for Costa Rica.

${ }^{5}$ Cf. Coudert (1999).
} 
a matter of fact, as price stabilisation was a key concern for policy-makers in the early 1990s, pegging the Hungarian forint was intended to provide a nominal anchor for inflationary expectations. As high as $35 \%$ per annum in 1991, inflation was brought down to about $20 \%$ as soon as in 1993 and 1994, which remained stuck at that level. At the same time, a substantial real appreciation was brought about by annual devaluations well below the annual CPI differential vis-à-vis the currency basket. This appreciation might have been inappropriate for several reasons. One big reason is that it negatively affected export performance going in tandem with skyrocketing imports, which paved the way for a first-generation type balance of payments crisis. This was accompanied by a loosening stance of monetary and fiscal policy reflected in very low real interest rates and an ever-widening deficit of the general government. In this context, an infamous austerity package including among others a range of structural reforms was announced in March 1995. Among others, the Hungarian currency was devalued by $9 \%$ and a pre-announced crawling peg system has been introduced. Efforts have been made to restore the internal and external balance. Since 1995, the monetary policy' main goal has been sustainable disinflation, which has aimed at reducing inflation by controlling for internal and external balances. Thus, the intermediate goal has long been the nominal and real exchange rate. As a result, till May 2001 with a fluctuation band of $\pm 2.25 \%$ around the central parity appreciation of the real effective exchange rate has ranged somewhere between $1.5 \%$ and $3 \%$, which could be considered by many as sustainable (C.f. Halpern-Wyplosz (2001), Kovács-Simon (1998)). The rate of crawl being close to zero and inflation stuck at $10 \%$, the margins have been enlarged to $\pm 15 \%$ and inflation targeting introduced. The crawling peg has been definitely abandoned in October 2001. Due to good overall economic performance, the nominal exchange rate quickly appreciated within the bands and inflation started to decrease rapidly (partly because of favourable food and oil price developments). At the same time, the current account position proved to be quite stable as did the stance of fiscal policy, although loosening with general elections ahead in April 2002.

Like Hungary, Slovenia also experienced real exchange rate appreciation in the first four-five years of its transition process. As announced to the IMF, the country had a floating exchange rate regime. In practice, however, the Bank of Slovenia has been heavily managing the nominal exchange rate against the deutsche mark so as to avoid excessive real appreciation by taking the home - foreign inflation differential into account, which could jeopardise external competitiveness. This was actually a non pre-announced but de facto crawling peg system. Real exchange rate targeting was indeed not officially announced as the central bank was officially targeting tight money. However, there have been conflicts between the two targets since tight monetary conditions have been aiming at achieving lower inflation and thus put pressure on the tolar to appreciate. At the same time, exchange rate interventions tended to slow disinflation. In 1995, the real effective exchange may be overvalued according some analysts. Hence, in the face of concerns about competitiveness, the Bank of Slovenia depreciated the currency by $11 \%$ through actively intervening in the foreign exchange market. Too slow restructuring in the enterprise sector, reflected in the slowdown in exports, and a unit labour cost by far outpacing productivity advances, the trade balance has started to deteriorate since late-1994. Simultaneously, the large current account surplus disappeared and turned into slight deficit in 1995. It is worth emphasising that fiscal policy has been very rigorous, in balance till 1999. Since January 1996, there has been a return to the unannounced narrow band. In May 1997, a new monetary framework was introduced by identifying M3 as an intermediate target. Nevertheless, the exchange rate targeting was not dropped and continued to be at work till 1998. Pressure on the exchange rate is now building due to public finances in the red from 1999 onward and the 
ongoing liberalisation of capital flows according to the Association Agreement between Slovenia and the EU. However, nominal exchange rate volatility is far lower than in other CEECs.

When it comes to assessing real exchange rate movements in Slovakia, three major periods can basically be distinguished. 1993-1996 was a period with strong real appreciation accompanied by good macroeconomic performance, 1997-1998 is the aftermath of the real appreciation with severe external imbalances and 1998-2001 can be characterised by a depreciated and more volatile real effective exchange rate due to free floating. To begin with, after a $10 \%$ devaluation in January 1993, the Slovak currency was pegged to a currency basket. The Slovak coruna was never devaluated until October $1,1998^{6}$. As a result, inflation was brought under control very rapidly and fell under $10 \%$ in 1995 . The other part of the story is the substantial real appreciation of the Slovak currency. Nevertheless, during this period the economy recovered driven by strong export performance. For a while, the external current account registered convenient surpluses in 1994 and 1995. In addition, the frightening 7\% to GDP deficit of general government in 1993 was corrected to as low as $1.3 \%$ relative to GDP in 1994 and turned to surplus in 1995. But 1996, the beginning of the second period, has been something of a nightmare for Slovakia: the external current account deteriorated quickly and there was new red ink in public finances. For the external position to worsen, one major reason was the substantial real appreciation of the home currency. In addition, real wages increased by far faster than productivity. Consequently, in spite of import surcharges ranging from $7 \%$ to $10 \%$ in 1995-1996, import grew sharply during the period, triggered by consumers hungry for foreign goods and by need for machinery for investment ${ }^{7}$. The stance of monetary policy expansionary till mid-1996, it began to be tightening in the face of the booming domestic demand. Even if domestic credit and money supply was brought under control, foreign borrowing continued to rise and so domestic pressure was not affected. However, interest rates skyrocketed both in nominal and real terms, financing the budget deficit turned out to be tough. As a result, with gross external debt nearly doubled in 3 years, major rating agencies downgraded Slovakia's sovereign debt. Bearing the deterioration of the fundamentals in mind, it was no surprise that in May 1997, the Slovak coruna came under speculative attack triggered by the turmoil on the Czech foreign exchange market. Since late1998 , the coruna is floating and slightly appreciating in nominal terms.

As part of the former Czechoslovakia, the Czech Republic started the transition process with a fixed exchange rate regime, with the national currency pegged to a basket of $65 \%$ German mark and $35 \%$ dollar US. Like in the case of Slovakia, the fixed nominal exchange rate, adjusted a couple of times till 1993 helped bring down inflation brought about by price liberalisation. From 1993 onward, date of the separation of the Czech Republic and Slovakia, the nominal exchange rate was maintained fixed against the basket till the coruna crisis in 1997. It is true to say, that economic transformation was rather slow and privatisation was meant to be accomplished by the

\footnotetext{
${ }^{6}$ However, in July 15 1995, the basket has been modified in that it contains but $40 \%$ USD and $60 \%$ DEM. In addition, while existing, the exchange rate system has undergone changes on several occasions with respect to the fluctuation band around the official rate (from January 1996 till July 1996: $\pm 3 \%$, between July 1996 and December $1996: \pm 5 \%$, and from January 1997 onward: $\pm 7 \%$ ). It should be also noted that the Slovak currency became fully convertible according to Article VIII of the IMF in October 1, 1995.

${ }^{7}$ The structure of foreign trade is essentially composed of products with low value-added such as steel, basic chemicals, fuels etc. which are very sensitive to price changes in row materials and EU business cycles. Moreover, Slovakian exports are heavily concentrated not only regarding sectors but also with respect to the number of companies.
} 
way of the voucher method. Unemployment stabilised at an astonishing low level of 3-4\% by Eastern European standards. At the same time, the position of public finances proved to be balanced as budgetary transfers were stopped towards Slovakia. Despite the successful stabilisation of the price inflation, like in Slovakia, the rate of growth of the price level remained too high. Keeping in mind the fixed exchange rate regime, it led to a considerable appreciation of the Czech currency in real terms. The signs of slow restructuring appeared first in late 1995, as the current account started to deteriorate and public finances dived into red. This phenomenon was just aggravated by the substantial real appreciation. In addition, the Czech Republic moved quickly towards current account convertibility and from 1996 on towards liberalisation of capital movements. As a result, the Czech currency had a lively exchange rate market in London. As in the case of Mexico in 1995, a kind of self-fulfilling speculation against the Czech currency began in London accompanied with the withdrawal of capital invested in short-term government papers as investors became aware of difficulties in economic reforms. Widening the narrow band of $\pm 0.5 \%$ to $\pm 7 \%$ in 1996 could not avoid the abandon of the pegged exchange rate regime in May 1997. The financial crisis quickly affected the real sphere. Under fixed exchange rate regime, Czech companies heavily indebted in foreign currencies, largely in the short term. Not only the sudden nominal depreciation increased the burden of servicing the short-term credit, but the renewal of credits proved to be very difficult if not impossible both abroad and at home. The banking system, already in bad shape, had to face sky-high nominal and real interest rates, reinforcing sensibility against risks. The consequence of the credit crunch and the bad loan load was a two-year long economic recession. Policy-makers learnt the lesson and the method of privatisation shifted towards direct sales mainly to foreign multinational firms. This and a large amount of FDI begin to appreciate the nominal exchange rate against the euro a substantial way from 1998 onward. As a results, the real exchange rate has been on a sharp appreciating path since.

As far as Poland goes, a pre-announced crawling peg was introduced in March 1991. This system had the merit to bring down inflation with a reasonable appreciation of the effective real exchange rate. That is the main reason why Poland did not have to struggle with overvalued currency till about 1996-97. During 1992-1996, there was no major problem as to the external and internal balances. However, as soon as the debt relief obtained from foreign creditors in 1994 and the deep rooted economic restructuring - briefly, confidence was back again - started to feel its effects, foreign capital in form of portfolio investment and FDI started to pour into Poland, which put tremendous pressure on the zloty. With gradual capital liberalisation as a background, the fluctuation band had to have been gradually widened to $\pm 7 \%$ in 1995 and then to $\pm 15 \%$ in 1999 and finally abandoned in spring 2000. Recently, free floating is producing erratic nominal and thus real exchange rate movements. It is noteworthy that from 1999-2000 onward, the Polish currency could be referred to as an overvalued currency. The main problem has been inflation due to domestic credit expansion, that the national bank tries to combat with high real interest rates. As all this tends to attract large speculative capital inflows, the zloty is on an appreciating path both in nominal and real terms. A strong domestic currency and high real interest rates hit hard exports, which coupled with budgetary problems provoked high current account deficits close to $8-9 \%$ to GDP in recent years. 
Figure 1. Effective real exchange rate movements, 1991:Q1-2001:Q2
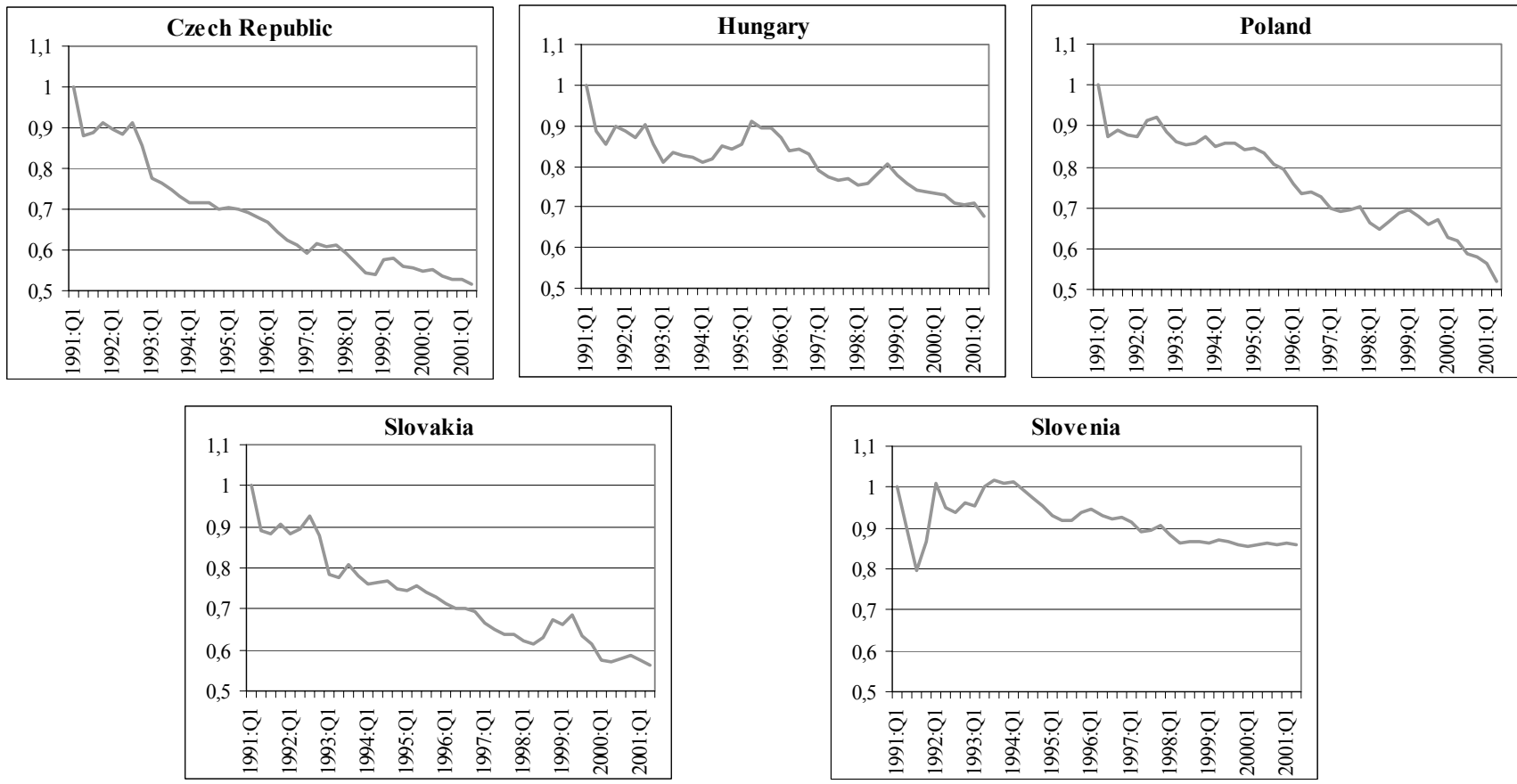

Note: Author's own calculations. For more detail, see Section VI.

\section{An overview of the literature}

When it comes to estimating the equilibrium real exchange rate for the accession countries, one can distinguish between three types of estimations as regards the theoretical background: It is common practice to test an extended Balassa-Samuelson model. When the dual productivity growth differential is not available, it is often proxied by other variables such as GDP per capita, variables connected to education and demographic factors. Short-term demand-side variables such as private and public consumption as a share of GDP is employed. A second strand of papers employs the reduced form equation derived from a general equilibrium model. Finally, the estimation of large macro-econometric models should be mentioned.

Apart from the different theoretical models used as a background, it is also possible to distinguish between studies regarding the econometric techniques employed: studies based on time series and on panel data. Using time series techniques allows to identify country-specific factors. However, the lack of data on a quarterly or monthly basis required by the short time span (roughly 10 years of transition) may force to switch to annual data and thus employ panel techniques (as it is impossible to conduct time series analysis on 10 observations).

\section{III.A. Time series studies}

Using time series, one can rely either on the estimation of a structural macroeconometric model or upon the single-equation approach. The only attempt that has been so far made to evaluate ERER in accession countries using macromodels is that of Smĭdkova (1998). Using the FEER approach, the first step of the analysis is to estimate the elasticity of the current account (CA) to domestic (Y) and foreign $\left(\mathrm{Y}^{*}\right)$ income and to the real effective exchange rate 
$\left(\mathrm{CA}=\mathrm{CA}\left(\mathrm{Y}, \mathrm{Y}^{*}, \mathrm{REER}\right)\right.$. Subsequently, a value for the REER should be determined so that $\mathrm{CA}, \mathrm{Y}$ and $\mathrm{Y}^{*}$ converge towards their equilibrium values. However, this would imply that the REER should affect three variables at the same time. For this reason, it is supposed in practice that internal balance is achieved independently of the REER. So, the current account compatible with internal balance is determined. Finally, the REER is derived which would move the current account modified for internal balance to its target value. Smĭdkova uses the Czech module of the NIGEM model of the NIESR estimated upon quarterly data over the period of 1992 to 1996 . She establishes two scenarios and determines two bands of overvaluation. These results suggest, the Czech koruna be overvalued compared to its estimated level by somewhere between $0.4 \%$ to $6.8 \%$ and $-1.4 \%$ to $5.4 \%$ in 1996 .

The alternative and more often employed way to estimate the ERER is the single-equation approach to the Behavioural Equilibrium Exchange Rate (BEER, cf. Clark-MacDonald (1998)). Actually, the BEER approach consists of the following five steps:

1.) The relationship between the ERER and a number of fundamentals and transitory factors is first estimated, mainly using the cointegration technique as the series usually turn out to be I(1) processes.

2.) The transitory effects are set to zero and the actual values of the fundamentals are simply substituted into the estimated relationship. The actual misalignment from equilibrium is then obtained by comparing the actual RER to the estimated one.

3.) The long-term or sustainable value of the fundamentals is then estimated either decomposing the series in question into permanent and transitory components (e.g. Hodrick-Prescott filter, Beveridge-Nelson decomposition) or evaluating subjectively the long-run value (cf. Baffes et al. (1999)).

4.) The estimated long-term values are substituted into the estimated (cointegration) relationship connecting ERER and fundamentals. At the same time, the variables playing a short-term role in the ERER determination are set to zero.

5.) To derive the extent of the total misalignment from equilibrium, the difference of the actual and the estimated equilibrium real exchange rate as in step 4.) is calculated. Thus, the total misalignment depends on the short-term transitory factors and the departure of the fundamentals from their long-term value. Alternatively, Clark and MacDonald (2000) show that it is also possible to obtain the total misalignment decomposing the cointegration vector itself into a permanent and a transitory component (Permanent Equilibrium Exchange Rate PEER) via the Gonzalo-Granger method. Thus, after estimating the long-run relationship, there is no need to evaluate long-term values for the fundamentals.

The number of studies using the BEER approach is somewhat higher compared to that employing the FEER approach. For example, a study by the IMF (1998) examines the case of Slovakia. Given the stationary nature of the variables, an OLS-type regression of real exchange rates is run using both fundamental and monetary factors to explain real exchange rate developments for monthly data between 1990:1 and 1997:2-6. The short-run monetary variables then are set to zero and the equilibrium path of the real exchange rate is computed. Finally, the estimated equilibrium and the actual real exchange rate are compared in order to determine the actual misalignment from equilibrium. The macroeconomic variables used are public consumption, investment, the openness ratio measured as (exports+imports)/GDP and real wages as a proxy for productivity. According to estimates, each variable seems to be significant. The openness, real wages and a 
proxy for monetary conditions all bear a positive relationship to the CPI, PPI and the unit labour cost-deflated real exchange rate. As to public consumption and investment they have a negative sign. The Slovak koruna is found not to be overvalued in 1996. This finding is at odds with the general perception that overvaluation was one big reason for the large external current account deficit.

In another paper, Avallone and Lahrèche-Révil (1998) study the equilibrium real exchange rate in Hungary during 1985 and 1997. Employing the Johansen cointegration technique to quarterly data, they proceed to the estimation of a cointegration vector including the CPI-based real effective exchange rate, public and private consumption, terms of trade defined as export prices/import prices, and GDP per capita as a proxy for productivity. They then measure the actual misalignment from equilibrium as the difference between the actual real effective exchange rate and the fitted values of the cointegration vector and conclude that the Hungarian currency was not overvalued in real terms during the period under consideration.

Two economists of the Czech National Bank, Frait and Komarek (1999) investigate the case of the Czech Republic. The Johansen cointegration technique is used for a dataset running from 1992:Q3 to 1998:Q4. The cointegrating vector links the real effective exchange rate to the terms of trade, a "world" interest rate, savings and GDP per capita. Substituting the long-run value of the fundamentals into the estimated equation, they compute the total departure of the real exchange rate from the equilibrium real exchange rate and conclude that the Czech koruna was close to equilibrium till 1996, slightly overvalued prior the koruna currency crisis, thereafter a bit undervalued and finally was overvalued compared to its estimated equilibrium value till 1998.

In a working paper of the National Bank of Estonia, Filipozzi (2000) investigates a possible departure of the ERER of the Estonian kroon against its equilibrium value. Once again, the cointegration technique is employed over the period from 1993:Q2 to 1999:Q2. The presence of a well specified cointegrating vector is detected containing the real effective exchange rate, the labour productivity differential between the open and sheltered sectors, investment, the trade balance and the nominal effective exchange rate. Several scenarios are dressed as to the long-term value of the fundamentals. While results suggest a total overvaluation of $25-30 \%$ at the beginning of the period, the overvaluation seems to drop to as low as about 5\% in early 1999 .

\section{III.A. Studies based on panel data}

The philosophy behind the use of panel data is somewhat different compared to the time series analysis. Estimating the relationship between the real effective exchange rate and the fundamentals enables us to obtain some kind of "average" coefficients for a set of countries.

The idea is that these "average" coefficients obtained from the panel could describe well the longterm behaviour of the individual countries' real exchange rate. To put it simply, in the long run, the real exchange rate is supposed to react to changes in fundamentals similarly in each country. The substitution of the observed fundamental time series into the estimated equation would yield the equilibrium real exchange rate for each country. As in the time series case, the misalignment from equilibrium can then be computed as the differential of the observed REER and the estimated equilibrium real exchange rate. 
We can distinguish between two types of panel studies: those relying on "in-the-sample" estimation of the equilibrium real exchange rate and those performing "out-of-sample" evaluation of the equilibrium real exchange rate. "In-the-sample" means in fact that the equilibrium real exchange rate is examined for the countries included in the panel and for the time span covered by panel data. On the contrary, the "out-of-sample" estimation means that the equilibrium real exchange rate is estimated for countries and for periods not included "in the sample". E.g., it is possible to estimate an equation linking real exchange rate and fundamentals for a given number of countries covering a given period. Then, the estimated equation is used to asses the equilibrium real exchange rate for a country not included in the panel.

Among the few panel studies Coudert (1999) regresses the US dollar-based and CPI-deflated real exchange rate on the productivity differential and on the foreign indebtedness ratio. The relative price of non-tradables and GDP per capita are used as a proxy for the productivity growth differential across countries. The panel is based on annual data for the period between 1977 and 1997 concerning a set of 16 emerging market economies of Asia, Latin American and Europe including Hungary as the only accession country. According to different panel estimation methods, the coefficients are all significant and range from -0.93 to -1.29 and from -0.32 to 0.45 respectively for the relative price differential and the indebtedness ratio and thus provide strong evidence in favour of the fact that the stock of dept compared to GDP has a large impact on real exchange rate movements in those countries. Results suggests the absence of sustained under- or overvaluation periods for Hungary during the whole period in general and for the period covering the 1990 s in particular.

In their seminal paper, Halpern and Wyplosz (1997) analyse a score of transition countries. Their theoretical assumption is that in the early years of transition, real exchange rates are well beneath their equilibrium value. It is mostly because of this "undershooting" that the real exchange rate will experience an appreciation till equilibrium level is reached. Moreover, even if real exchange rates are close to their equilibrium value, there is still room for appreciation since the equilibrium rate is expected to undergo to appreciation mainly due to higher inflation rates. Higher overall inflation can be explained by the Balassa-Samuelson effect, improvement in traded goods' quality and relative wage adjustments. So as to measure the misalignment from the equilibrium real exchange rate, they first estimate a real dollar wage equation including variables such as GDP per capita as a proxy for productivity, school enrolment, the share of agriculture in GDP, government consumption. This estimate is based on pooled time series for 80 countries of approximately the same level of development. 5 observations are included for each country $(1970,1975,1980$, 1985, 1990). Results suggest that GDP per capita, school enrolment and government consumption are positively related to dollar wage, while the agriculture/industry ratio and inflation have negative signs. They then determine the equilibrium dollar wage by substituting the corresponding time series (1990-1996) for the transition countries into the estimated equation and compare it with actual dollar wages. Results support the theoretical assumptions as all countries but Hungary and Slovenia had undervalued real exchange rates at the beginning of transition. They draw the conclusion that by 1996, the real exchange rate is near to its equilibrium level for Croatia, the Czech Republic, Poland, Slovenia and Hungary.

Begg, Halpern and Wyplosz (1999) update the data base used in Halpern and Wyplosz (1997): the number of countries is extended to 85 and the period is augmented with the observation for 1995 . Additional variables such as the dependence ratio, the openness ratio, net foreign assets of the 
banking sector and of the economy, credit to private sector and a number of regional dummies for OECD countries, countries of the former soviet bloc and of the Commonwealth of Independent States (CEI) are added. They estimate the equilibrium dollar wage for 12 transition countries for the period 1990-1997: the equilibrium dollar wage seems not to appreciate any more in 1996 and 1997 for some countries. On the one hand, the currency of the Baltic states and the Czech and Slovak Republics were substantially undervalued in real terms in the early 1990 but converged rapidly to their equilibrium value. On the other hand, the case of Hungary, Poland and Slovenia is close to overvaluation from 1996 on.

The study of Krajnyák and Zettelmeyer (1997) is somewhat similar to Halpern and Wyplosz (1997) in that they estimate the equilibrium dollar wage using a large panel including 85 countries, 15 transition economies among others. The data base contains 6 annual observations for each country between 1990 and 1995. The variables which are expected to capture real exchange rate movements are GDP per capita, school enrolment and the share of agriculture in GDP. In addition, a score of other variables are used aiming at describing the institution settings such as an indicator for central interventions, for fiscal regime, property right and economic freedom. According to the results, in the early 1990s, the equilibrium dollar wage appreciated in Bulgaria, the Czech Republic, Estonia, Hungary, Poland, Romania and Slovakia. At the same time, the observed dollar wage, undervalued at the beginning, converged to its equilibrium value.

In a recent study covering 12 CEECs and the period 1990-1998, Maurin (2001) considers the productivity growth differential between the open and the sheltered sector, public consumption, real domestic interest rate and the external debt. Assuming progress in non-tradable productivity to be equal to zero, the productivity differential is given by productivity advances in the tradedgoods sector. Proxies for productivity are per capita GDP and the relative price of nontradables, that is consumer prices compared to industrial prices. Public consumption and external debt are expressed in terms of GDP. The key finding of the paper is that public consumption and external debt are correctly signed, that is to say have a positive and negative sign, the coefficient ranging from 0.80 to 1.37 and from -0.55 to -0.83 respectively. As for productivity, coefficients are almost never significant whatever the proxy may be and have the expected positive sign when per capita GDP is considered.

De Broeck and Sløk (2001) investigate real exchange rates in transition countries. The study covers two groups of transition countries. The one we are interested in is the EU accession countries' group which includes the three Baltic States, Bulgaria, the Czech Republic, Hungary, Poland, Romania, Slovakia and Slovenia. Data are gathered on a yearly basis over the period 1991 to 1998. In a panel framework, the real effective exchange rate provided by the IMF is regressed on the productivity growth differential across the open and the sheltered sector related to exports-weighted average productivity growth differential of 18 OECD countries. The productivity variable turns out to be significant and has the expected sign - that is an increase in productivity differential implies a real appreciation of the exchange rate. The coefficient of the productivity variable varies between 0.2 to 0.8 . In addition, other variables are introduced so as to control for short-and long-term fluctuations caused by other fundamental factors. The openness and government balance variables become significant with the correct sign. The more open the country is, the stronger the push towards depreciation is on the one hand, and the higher the government deficit, the larger the depreciation in real terms, on the other. The terms of trade, fuel and non-fuel prices then become insignificant in their estimates. 


\section{The Model}

The theoretical framework is given by the model proposed by Montiel (1999). In fact, the model is designed for a small, open economy, based on two sectors. The open sector produces tradable goods while the sheltered sector produces non-tradable goods. In addition, the representative household maximises its intertemporel consumption of tradable and non-tradable goods. Finally, the consolidated public sector is considered, including general government and the central bank. The real exchange rate is defined as the price of non-tradables to the price of tradable goods. The exposed and sheltered sectors can be described with two different CobbDouglas production functions as follows:

$$
\begin{aligned}
& \mathrm{Y}^{\mathrm{T}}=\mathrm{A}^{\mathrm{T}} \cdot\left(\mathrm{L}^{\mathrm{T}}\right)^{\alpha}\left(\mathrm{K}^{\mathrm{T}}\right)^{(1-\alpha)} \\
& \mathrm{Y}^{\mathrm{NT}}=\mathrm{A}^{\mathrm{NT}} \cdot\left(\mathrm{L}^{\mathrm{NT}}\right)^{\beta}\left(\mathrm{K}^{\mathrm{NT}}\right)^{(1-\beta)}
\end{aligned}
$$

where $\mathrm{A}^{\mathrm{T}}, \mathrm{A}^{\mathrm{NT}}, \mathrm{L}^{\mathrm{T}}, \mathrm{L}^{\mathrm{NT}}, \mathrm{K}^{\mathrm{T}}$ and $\mathrm{K}^{\mathrm{NT}}$ stand for total factor productivity, labour and capital in the open and sheltered sectors respectively. Households maximise an infinite intertemporel utility function if their present and future consumption of tradable and non-tradable goods with a dynamic budgetary constraint. Besides the choice of the optimal intertemporel consumption, they also determine the optimal allocation of tradables and non-tradables the following way:

$$
\operatorname{MAX} \int \mathrm{U}\left(\mathrm{C}^{\mathrm{T}}, \mathrm{C}^{\mathrm{NT}}\right) \exp (-\mathrm{pt}) \mathrm{dt}
$$

where $\mathrm{C}^{\mathrm{T}}$ et $\mathrm{C}^{\mathrm{NT}}$ denote respectively the consumption of tradables and non-tradables. Assuming the elasticity of the intratemporal substitution between tradables and non-tradables to be unity, the utility function can be written as follows:

$$
\mathrm{U}\left(\mathrm{C}^{\mathrm{T}}, \mathrm{C}^{\mathrm{NT}}\right)=\frac{\left[\left(\mathrm{C}^{\mathrm{T}}\right)^{\theta}\left(\mathrm{C}^{\mathrm{NT}}\right)^{1-\theta}\right]^{1-\frac{1}{\sigma}}}{1-\frac{1}{\sigma}}
$$

$\theta$ and $\sigma$ denoting respectively the share of tradable goods in total consumption and the elasticity of intertemporel substitution. A Cobb-Douglas-style specification of the elasticity of intratemporal substitution between tradables and non-tradables makes it possible to divide consumption into tradable and non-tradable consumption as follows: $C^{T}=\theta C, C^{\mathrm{NT}}=(1-\theta) \mathrm{Q}$, where $C=C^{T}+C^{N T} / Q$. Substituting these equations into equation (3), we obtain:

$$
\mathrm{U}\left(\mathrm{C}^{\mathrm{T}}, \mathrm{C}^{\mathrm{NT}}\right)=\frac{\mathrm{k}\left[\mathrm{Q}^{1-\theta} \mathrm{C}\right]^{1-\frac{1}{\sigma}}}{1-\frac{1}{\sigma}}
$$

where $\mathrm{k}$ is a constant and $\mathrm{Q}$ stands for the real exchange rate. We then proceed to maximise equation (4) under the dynamic budgetary constraint (BC) given by net wealth accumulation of households. Net wealth accumulation is determined by savings and earnings on domestic and foreign bonds $\left(\mathrm{B}^{\mathrm{D}}\right.$ and $\left.\mathrm{B}^{\mathrm{F}}\right)$, and by the holding of the home currency $(\mathrm{M})$.

$$
B C_{t}=\left[Y_{t}-C_{t}-T_{t}\right]+\left\lfloor\left(i^{*}+d-\pi\right) B_{t}{ }^{F}+(i-\pi) B_{t}{ }^{D}-i M_{t}\right\rfloor
$$

where $\mathrm{Y}, \mathrm{C}$ et $\mathrm{T}$ denote total production, total consumption and taxes paid by households. Foreign and domestic bond in the households' portfolio yield the foreign and domestic interest rate $\left(i^{*}, i\right)$ 
and are connected via the uncovered interest rate parity corrected for risk premium $(\rho)$. Risk premium is indeed a function of the probability of the collapse of the fixed exchange rate regime:

$$
\mathrm{i}=\mathrm{i}^{*}+\mathrm{d}+\rho(\mathrm{NFA})
$$

where $\mathrm{d}$ and NFA stand for the devaluation of the nominal exchange rate and net foreign assets. The term iM in equation (5) represents the opportunity cost of holding national currency. We note that the real exchange rate is defined as the ratio price of tradables/ price of non-tradables. The nominal exchange rate is thus supposed to be stable over time. Considering equation (4) and the budget constraint and assuming $\lim \int_{\mathrm{t}=1}^{\infty} \mathrm{BC}_{\mathrm{t}} \exp (\mathrm{dt}) \geq 0$, the optimal path of consumption is given by:

$$
\dot{\mathrm{C}}=\frac{1}{\sigma}\left[\mathrm{r}+\gamma \frac{\dot{\mathrm{Q}}}{\mathrm{Q}}-\psi\right] \mathrm{C}
$$

where $\gamma=(1-\sigma)(1-\theta)$ and $\psi$ denote the parameter of temporal preference. In fact, what we can see from equation (7) is that optimal consumption is determined by the real interest rate, the real exchange rate, the intertemporel preference parameter, the share of tradables in total consumption and finally the elasticity of intertemporel consumption. As to general government including the central government and the Central bank, we define the budget constraint $\left(\mathrm{BC}^{\mathrm{G}}\right)$ as follows:

$$
\mathrm{BC}^{\mathrm{G}}=[\mathrm{T}+\mathrm{i} \cdot \mathrm{B}+\pi \cdot \mathrm{m}]-\left[\mathrm{G}^{\mathrm{T}}+\mathrm{G}^{\mathrm{NT}}\right]
$$

where $\mathrm{T}, \mathrm{iB}, \pi \mathrm{M}, \mathrm{G}^{\mathrm{T}}$ and $\mathrm{G}^{\mathrm{NT}}$ stand respectively for taxes, net public debt, inflation tax and public consumption on tradables and non-tradables. Respecting the budget constraint does not necessarily mean balanced budget but rather a sustainable public debt in the medium and long term. In the model, the equilibrium real exchange rate is defined in terms of internal and external balances. Internal balance is achieved when the market for non-tradable goods is in equilibrium: That is, households and the government consume all the produced non-tradable goods as in equation (9):

$$
\mathrm{Y}^{\mathrm{NT}}(\mathrm{Q})=\mathrm{C}^{\mathrm{NT}}+\mathrm{G}^{\mathrm{NT}}
$$

Where $Y_{N T}$ stands for output in non-tradables and $C^{\mathrm{NT}}$ and $\mathrm{G}^{\mathrm{NT}}$ denote the respective consumption of households and general government on non-tradable goods. As far as external balance is concerned, equilibrium is reached when the current account, that is national savings equal to gains or losses on net foreign assets according to equation (10):

$$
\pi_{M} A E N=Y^{T}(e)+\left(\rho+\pi_{M}\right) A E N-\theta C-G^{T}
$$

\section{Empirical Approach}

We propose to estimate a VAR-based 3-equation cointegration system. Internal balance is defined in terms of relative prices and external balance is determined as the sustainable value of the current account (deficit/surplus). Then, the equilibrium real exchange rate is obtained as a function of internal and external balances. Thus, the first cointegration relationship of the systems 
consists of relative prices (REL), the dual productivity growth differential (PROD) and private consumption (PRIVCON). The second one includes the current account (CA), the terms of trade (TOT) and the degree of openness of the economy (OPEN). Finally, we proceed to estimate the cointegration vector comprising the real exchange rate (RER), relative prices and the balance of the current account:

Internal balance $(\mathrm{X} 1)$ :

$$
\begin{aligned}
& \text { REL }+\beta_{1} \cdot \text { PROD }+\beta_{2} \cdot \text { PRIVCON } \\
& \text { CA }+\beta_{1} \cdot \text { TOT }+\beta_{2} \cdot \text { OPEN } \\
& \text { RER }+\beta_{1} \cdot \mathrm{REL}+\beta_{2} \cdot \mathrm{CA}
\end{aligned}
$$$$
\text { External balance (X2) : }
$$

The three cointegration vectors are normalised to relative prices, the current account and the real exchange rate, respectively. As a matter of fact, we estimate a VAR and try to identify the above cointegration relationship with implementing the Johanson trace tests. Having identified the cointegration vectors, we can obtain the estimated values for relative prices and the current account. These values can be referred to as the long-term or the estimated equilibrium values for relative prices and the current account. Next, we substitute these estimated values into equation (13) so as to derive the equilibrium real exchange rate. Finally, the obtained equilibrium real exchange rate is compared with the observed real exchange rate: the gap between the estimates and the observed values can be interpreted either as an excessive real appreciation or an excessive real depreciation of the home currency.

\section{Data}

We use a quarterly data set covering 1992:Q1 - 2001:Q2 for Hungary, Poland and the Czech Republic and 1993:Q1 - 2001:Q1 for Slovakia and Slovenia. The effective real exchange rate is based on the German mark and the US dollar. The weights we use for computing the effective real exchange rate correspond to the structure of foreign trade in terms of $(\mathrm{X}+\mathrm{M}) / 2$ vis-à-vis the EU-15 (for the deutschemark) and the rest of the world (for the US dollar). The nominal exchange rate, issued from the "WIIW Countries in Transition 2001" database 8 , is expressed in foreign currency terms and is calculated as a three-month average. The nominal exchange rate is then deflated by the corresponding cumulated foreign and domestic CPI series coming from the OECD's database. The relative price of non-tradable goods compared with that of tradable goods is calculated as service price series relative to the PPI for industrial goods. The series are calculated in effective terms (against the Germany - US basket) and are obtained from the OECD. The balance of the current account is obtained as the ratio of the cumulated series of the current account to GDP. The dual productivity growth differential is based on labour productivity data: we divide the index for industrial production with the index of employees in industry. The domestic productivity series is then compared to the foreign productivity ratio. The source of data is the OECD. Private consumption is linearly interpolated from annual data coming from the WIIW. Per capita GDP data expressed in purchasing power standards PPS are also obtained from the WIIW and are linearly interpolated from annual data. The terms of trade series, defined as the ratio of export prices to import prices come from Datastream. The openness variable is computed as (exports + imports)/GDP.

\footnotetext{
${ }^{8}$ Vienna Institute for International Economic Studies.
} 


\section{The Econometric Method}

We estimate the following VAR system including the variables discussed before:

$$
\Delta \mathrm{y}_{\mathrm{t}}=\sum_{\mathrm{i}=1}^{\mathrm{k}-1} \Gamma_{\mathrm{y}, \mathrm{i}} \Delta \mathrm{y}_{\mathrm{t}-\mathrm{i}}+\mu+\mathrm{v} \cdot \mathrm{t}+\Pi_{\mathrm{y}} \mathrm{y}_{\mathrm{t}-1}+\Psi \cdot \mathrm{d}_{\mathrm{t}}+\varepsilon_{\mathrm{t}}
$$

where $\mathrm{y}_{\mathrm{t}}$ is the vector of variables, $\mu$ and $v \cdot t$ are a constant and a trend, while $\Psi \cdot \mathrm{d}_{\mathrm{t}}$ represents the vector of intervention dummies. We included intervention dummies for a number of countries so as to control for possible structural breaks. A candidate phenomenon for causing shifts in fundamentals is the liberalisation of capital movements. Every single country under consideration has abolished, at a different pace, virtually all barriers to free capital movements. As a results, monetary and exchange rate policies have been deeply changed. We experienced to include centralised dummies for every country: statistically significant dummies could be found only for Hungary and the Czech Republic with the periods covered of 1991:Q1-0995:Q1 and 1995:Q22001:Q2 for Hungary and 1991:Q1-1996:Q4 and 1997:Q1 and 2001:Q2 for the Czech Republic. The question of the non-stationarity is dealt with not via the usual univariate ADF and PP unit root tests but rather by performing multivariate stationarity tests in the VAR-system. As results reported in Tables 1-5 show clearly that all variables are I(1) processes, the cointegration technique seems to be the appropriate estimation technique. In order to obtain robust estimates of the cointegrating vectors, we have to implement a number of specification tests. The lag lengths are determined so that no- auto-correlation and normality for the residuals are ensured. Furthermore, we implement likelihood ratio tests to determine the trend polynomial in the cointegrating vector ${ }^{9}$. The cointegration rank is determined using the Johansen cointegration test $^{10}$. The stability of the cointegration rank and the space $\beta$ are verified in line with suggestions in Hansen-Johansen (1993). Next, roots of the model and the auto-correlation and normality of the residuals are examined using correlograms and performing the Jarque-Bera multivariate test on the single equations' residuals and on the residual vector.

We expect that relative prices have a positive link to productivity and private consumption. In other terms, an increase (decrease) in productivity and in private consumption should bring about an increase (decrease) in relative prices. As to the current account, we hope to find it positively related to the terms of trade and negatively connected to openness. Put differently, an increase (decrease) in the terms of trade and a decrease (increase) in the openness is expected to provoke an improvement (deterioration) of the current account. It must be noted, however, that the expected sign for the terms of trade is controversial. Finally, the real exchange rate is expected to have a negative link to relative prices and the current account. An increase (decrease) in relative prices is to contribute to the appreciation (depreciation) of the real exchange rate. As to the current account, an improvement (deterioration) should make the real exchange rate appreciate

\footnotetext{
${ }^{9}$ Restrictions on the deterministic trend coefficients are tested for. The following five models can be distinguished: model $1(\mathrm{~m} 1)$ : the $\mathrm{I}(0)$ series have zero mean, the cointegrating vector does not have an intercept; model $2(\mathrm{~m} 2)$ : the $\mathrm{I}(0)$ series have non-zero mean, the cointegrating vector contains an intercept; model $3(\mathrm{~m} 3)$ : the $\mathrm{I}(0)$ series have linear trends, the cointegrating vector includes a constant; model $4(\mathrm{~m} 4)$ : both the $\mathrm{I}(0)$ series and the cointegrating equation have a trend; model $5(\mathrm{~m} 5)$ : $\mathrm{I}(0)$ series have a linear trend, and the $\mathrm{I}(1)$ component contains a quadratic trend.

${ }^{10}$ Only the trace test statistics are reported since the lambda-max test does not fit into a coherent testing strategy as noted in Johansen (1992)
} 
(depreciate). Technically speaking, the expected signs for the three cointegrating vectors can be summarised as follows: $\mathrm{X} 1=(1,-,-), \mathrm{X} 2=(1,-,+), \mathrm{X} 3=(1,+,+)$.

\section{Empirical Results}

We would like to emphasise that the results of the estimations reported in Tables 1-5 should be considered with prudence. Having tested the three-equation system for the 5 countries under study, it turns out to work properly, with the expected number of cointegration vectors having significant and correctly signed coefficients, for Hungary and Poland ${ }^{11}$. For the other three countries, problems mainly arise as regards productivity as it is generally not statistically significant and has the wrong sign. For this reason, we proceeded to replace productivity and private consumption with per capita GDP (CAPITA), measured in terms of PPS. Hence, we use the modified version of equation (11):

Internal balance $(\mathrm{X} 1): \quad \mathrm{REL}+\beta_{1} \cdot \mathrm{CAPITA}$

Estimating the modified system yields the expected results: we are able to identify three cointegration vectors, with correctly signed and statistically significant coefficients. The only exception to rule is the case of the terms of trade, which has systematically a positive sign, indicating that an improvement in the terms of trade is translated into a worsening current account.

\footnotetext{
${ }^{11}$ We note that the rang of cointegration is found to be 4 for Poland and the Czech Republic according to the Johansen trace statistics. However, as the stability tests reveal, only three vectors can be considered as stable over time.
} 
William Davidson Institute Working Paper 480

Table 1. Hungary, 1991:1-2001:2, Vector $=X \beta^{\prime}$

$\mathrm{X} 1=[\mathrm{REL}, \mathrm{PROD}, \mathrm{CONPRIV}], \beta^{\prime}=\left[1, \beta_{1}, \beta_{2}\right]$, expected signs $[1,-,-]$ $\mathrm{X} 2=[\mathrm{CA}, \mathrm{TOT}, \mathrm{OPEN}], \beta^{\prime}=\left[1, \beta_{1}, \beta_{2}\right]$, expected signs $[1,-,+]$ $\mathrm{X} 3=[\mathrm{RER}, \mathrm{REL}, \mathrm{CA}], \beta^{\prime}=\left[1, \beta_{1}, \beta_{2}\right]$, expected signs $[1,+,+]$

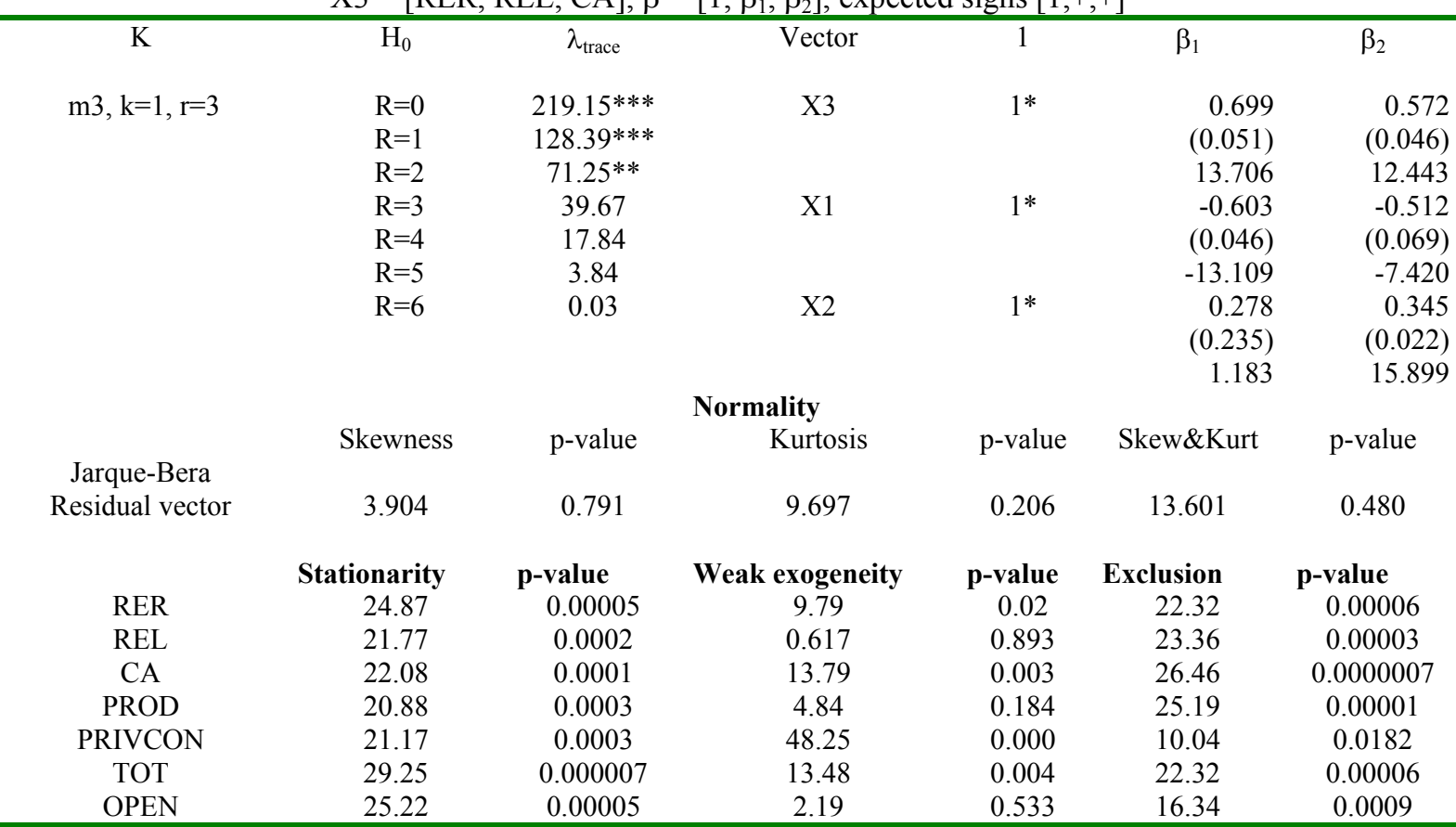

Note. $\lambda_{\text {trace }}$ is the Johansen statistics, critical values are those tabulated in Johansen(1996); * and ** indicate that $\mathrm{H}_{0}$ is rejected at the $5 \%$ and $1 \%$ significance level, respectively; the model tested for and the number of lags used in the model are in parenthesis below the Johansen statistics. Below $\beta_{1}$ values can be found the t-statistics of the CE in parenthesis. The asterisk above the 1 in column 5, (the beta to which the cointegrating vector is normalised) indicates that the variable is significant at the $5 \%$ level in another normalisation. As regards the Jarque-Bera normality test, $\mathrm{p}$-values are in parenthesis beneath $\chi^{2}$ statistics and refer to skewness and kurtosis: normality is accepted when the p-value is higher than 0.05 . 
William Davidson Institute Working Paper 480

Table 2. Poland, 1991:1-2001:2, Vector $=X \beta$,

$\mathrm{X} 1=\left[\right.$ REL, PROD, CONPRIV], $\beta^{\prime}=\left[1, \beta_{1}, \beta_{2}\right]$, expected signs $[1,-,-]$ $\mathrm{X} 2=[\mathrm{CA}, \mathrm{TOT}, \mathrm{OPEN}], \beta^{\prime}=\left[1, \beta_{1}, \beta_{2}\right]$, expected signs $[1,-,+]$ $\mathrm{X} 3=[\mathrm{RER}, \mathrm{REL}, \mathrm{CA}], \beta^{\prime}=\left[1, \beta_{1}, \beta_{2}\right]$, expected signs $[1,+,+]$

\begin{tabular}{|c|c|c|c|c|c|c|}
\hline $\mathrm{K}$ & $\mathrm{H}_{0}$ & $\lambda_{\text {trace }}$ & Vector & 1 & $\beta_{1}$ & $\beta_{2}$ \\
\hline \multirow[t]{11}{*}{$\mathrm{m} 1, \mathrm{k}=1, \mathrm{r}=3$} & $\mathrm{R}=0$ & $309.04 * * *$ & $\mathrm{X} 3$ & $1^{*}$ & 2.198 & 1.253 \\
\hline & $\mathrm{R}=1$ & $166.33 * * *$ & & & $(0.086)$ & $(0.103)$ \\
\hline & $\mathrm{R}=2$ & $87.11 * * *$ & & & 25.558 & 12.165 \\
\hline & $\mathrm{R}=3$ & $42.04 * *$ & $\mathrm{X} 1$ & $1 *$ & -0.286 & -0.539 \\
\hline & $\mathrm{R}=4$ & 17.81 & & & $(0.049)$ & $(0.045)$ \\
\hline & $\mathrm{R}=5$ & 7.05 & & & -5.837 & -11.978 \\
\hline & $\mathrm{R}=6$ & 1.16 & $\mathrm{X} 2$ & $1^{*}$ & 0.648 & 0.653 \\
\hline & & & & & $(0.106)$ & $(0.065)$ \\
\hline & & & & & 6.113 & 10.046 \\
\hline & & & Normality & & & \\
\hline & Skewness & p-value & Kurtosis & p-value & Skew\&Kurt & p-value \\
\hline Jarque-Bera & & & & & & \\
\hline \multirow[t]{2}{*}{ Residual vectors } & 6.876 & 0.442 & 5.562 & 0.592 & 12.438 & 0.571 \\
\hline & Stationarity & p-value & Weak exogeneity & p-value & Exclusion & p-value \\
\hline RER & 35.23 & 0.0000004 & 5.14 & 0.162 & 25.39 & 0.00001 \\
\hline REL & 32.12 & 0.000002 & 9.09 & 0.028 & 60.59 & 0.00000 \\
\hline $\mathrm{CA}$ & 31.37 & 0.000002 & 44.99 & 0.00009 & 53.46 & 0.00000 \\
\hline PROD & 33.01 & 0.000001 & 9.68 & 0.022 & 14.54 & 0.002 \\
\hline PRIVCON & 31.51 & 0.000002 & 90.60 & 0.00000 & 35.24 & 0.0000 \\
\hline TOT & 32.70 & 0.000002 & 42.83 & 0.00000 & 36.07 & 0.0000 \\
\hline OPEN & 33.77 & 0.0000008 & 8.04 & 0.045 & 34.62 & 0.0000 \\
\hline
\end{tabular}

Notes: as for Table 1.

Table 3. Slovenia, 1993:1-2001:2, Vector $=X \beta^{\prime}$

$\mathrm{X} 1=[\mathrm{REL}, \mathrm{CAPITA}], \beta^{\prime}=\left[1, \beta_{1}, \beta_{2}\right]$, expected signs $[1,-,-]$

$\mathrm{X} 2=[\mathrm{CA}, \mathrm{TOT}, \mathrm{OPEN}], \beta^{\prime}=\left[1, \beta_{1}, \beta_{2}\right]$, expected signs $[1,+]$

$\mathrm{X} 3=[\mathrm{RER}, \mathrm{REL}, \mathrm{CA}], \beta^{\prime}=\left[1, \beta_{1}, \beta_{2}\right]$, expected signs $[1,+,+]$

\begin{tabular}{|c|c|c|c|c|c|c|}
\hline $\mathrm{K}$ & $\mathrm{H}_{0}$ & $\lambda_{\text {trace }}$ & Vector & 1 & $\beta_{1}$ & $\beta_{2}$ \\
\hline \multirow[t]{11}{*}{$\mathrm{M} 3, \mathrm{k}=2, \mathrm{r}=3$} & $\mathrm{R}=0$ & $131.63 * * *$ & $\mathrm{X} 3$ & $1 *$ & 1.843 & -0.077 \\
\hline & $\mathrm{R}=1$ & $79.02 * * *$ & & & $(0.091)$ & $(0.006)$ \\
\hline & $\mathrm{R}=2$ & $47.34 * * *$ & & & 20.252 & -12.833 \\
\hline & $\mathrm{R}=3$ & 23.99 & $\mathrm{X} 1$ & $1 *$ & -0.746 & \\
\hline & $\mathrm{R}=4$ & 8.05 & & & $(0.013)$ & \\
\hline & $\mathrm{R}=5$ & 2.47 & & & 57.385 & \\
\hline & & & $\mathrm{X} 2$ & $1 *$ & -20.924 & 1.035 \\
\hline & & & & & $(0.274)$ & $(0.466)$ \\
\hline & & & & & -76.365 & -2.221 \\
\hline & & & Normality & & & \\
\hline & Skewness & $\mathrm{p}$-value & Kurtosis & $\mathrm{p}$-value & Skew\&Kurt & $\mathrm{p}$-value \\
\hline Jarque-Bera & & & & & & \\
\hline \multirow[t]{2}{*}{ Residual vectors } & 8.745 & 0.188 & 7.499 & 0.277 & 48.936 & 0.180 \\
\hline & Stationarity & p-value & Weak exogeneity & p-value & Exclusion & p-value \\
\hline RER & 19.91 & 0.003 & 11.51 & 0.009 & 11.74 & 0.008 \\
\hline REL & 11.37 & 0.009 & 11.62 & 0.008 & 24.10 & 0.0001 \\
\hline CA & 16.58 & 0.0008 & 4.36 & 0.225 & 12.13 & 0.007 \\
\hline CAPITA & 11.25 & 0.011 & 13.08 & 0.004 & 15.43 & 0.001 \\
\hline TOT & 14.86 & 0.002 & 11.61 & 0.009 & 11.20 & 0.011 \\
\hline OPEN & 18.67 & 0.0003 & 3.73 & 0.292 & 13.17 & 0.004 \\
\hline
\end{tabular}

Notes: as for Table 1. 
William Davidson Institute Working Paper 480

Table 4. Slovakia, 1993:1-2001:2, Vector $=X \beta$,

$\mathrm{X} 1=[\mathrm{REL}, \mathrm{CAPITA}], \beta^{\prime}=\left[1, \beta_{1}\right]$, expected signs $[1,-]$

$\mathrm{X} 2=[\mathrm{CA}, \mathrm{OPEN}], \beta^{\prime}=\left[1, \beta_{1}, \beta_{2}\right]$, expected signs $[1,+]$

$\mathrm{X} 3=[$ RER, REL, CA $], \beta^{\prime}=\left[1, \beta_{1}, \beta_{2}\right]$, expected signs $[1,+,+]$

\begin{tabular}{|c|c|c|c|c|c|c|}
\hline $\mathrm{K}$ & $\mathrm{H}_{0}$ & $\lambda_{\text {trace }}$ & Vector & 1 & $\beta_{1}$ & $\beta_{2}$ \\
\hline \multirow[t]{11}{*}{$\mathrm{M} 3, \mathrm{k}=1, \mathrm{r}=3$} & $\mathrm{R}=0$ & $123.98 * * *$ & $\mathrm{X} 3$ & $1 *$ & 0.246 & -0.102 \\
\hline & $\mathrm{R}=1$ & $75.13 * * *$ & & & $(0.048)$ & $(0.034)$ \\
\hline & $\mathrm{R}=2$ & $38.69 * * *$ & & & 5.125 & -3.000 \\
\hline & $\mathrm{R}=3$ & 11.69 & $\mathrm{X} 1$ & $1 *$ & -0.949 & \\
\hline & $\mathrm{R}=4$ & 0.119 & & & $(0.034)$ & \\
\hline & & & & & -27.912 & \\
\hline & & & $\mathrm{X} 2$ & $1 *$ & 1.471 & \\
\hline & & & & & $(0.089)$ & \\
\hline & & & & & 16.528 & \\
\hline & & & Normality & & & \\
\hline & Skewness & $\mathrm{p}$-value & Kurtosis & $\mathrm{p}$-value & Skew\&Kurt & p-value \\
\hline & & & & & & \\
\hline \multirow[t]{2}{*}{ Residual vector } & 7.118 & 0.212 & 8.499 & 0.131 & 15.617 & 0.111 \\
\hline & Stationarity & p-value & Weak exogeneity & p-value & Exclusion & p-value \\
\hline RER & 7.77 & 0.020 & 18.15 & 0.0004 & 27.05 & 0.000 \\
\hline REL & 20.26 & 0.000 & 25.21 & 0.00001 & 25.58 & 0.000 \\
\hline CA & 22.49 & 0.000 & 11.76 & 0.008 & 3.64 & 0.302 \\
\hline CAPITA & 13.06 & 0.001 & 15.38 & 0.0015 & 28.14 & 0.000 \\
\hline OPEN & 23.41 & 0.000 & 9.82 & 0.020 & 16.81 & 0.0007 \\
\hline
\end{tabular}

Notes: as for Table 1.

Table 5. Czech Republic, 1991:1-2001:2, Vector $=X \beta^{\prime}$

$\mathrm{X} 1=[\mathrm{REL}, \mathrm{CAPITA}], \beta^{\prime}=\left[1, \beta_{1}, \beta_{2}\right]$, expected signs $[1,-,-]$

$\mathrm{X} 2=[\mathrm{CA}$, TOT, OPEN $], \beta^{\prime}=\left[1, \beta_{1}, \beta_{2}\right]$, expected signs $[1,+]$

$\mathrm{X} 3=[\mathrm{RER}, \mathrm{REL}, \mathrm{CA}], \beta^{\prime}=\left[1, \beta_{1}, \beta_{2}\right]$, expected signs $[1,+,+]$

\begin{tabular}{|c|c|c|c|c|c|c|}
\hline $\mathrm{K}$ & $\mathrm{H}_{0}$ & $\lambda_{\text {trace }}$ & Vector & 1 & $\beta_{1}$ & $\beta_{2}$ \\
\hline \multirow[t]{11}{*}{$\mathrm{M} 3, \mathrm{k}=2, \mathrm{r}=3$} & $\mathrm{R}=0$ & $178.87 * * *$ & $\mathrm{X} 3$ & $1 *$ & 1.675 & 0.481 \\
\hline & $\mathrm{R}=1$ & $107.89 * * *$ & & & $(0.037)$ & $(0.035)$ \\
\hline & $\mathrm{R}=2$ & $65.98 * * *$ & & & 45.270 & 13.743 \\
\hline & $\mathrm{R}=3$ & $31.97 * *$ & X1 & $1 *$ & -0.907 & \\
\hline & $\mathrm{R}=4$ & 9.25 & & & $(0.049)$ & \\
\hline & $\mathrm{R}=5$ & 2.87 & & & -18.435 & \\
\hline & & & $\mathrm{X} 2$ & $1^{*}$ & 0.659 & 0.752 \\
\hline & & & & & $(0.110)$ & $(0.025)$ \\
\hline & & & & & 6.013 & 30.080 \\
\hline & & & Normality & & & \\
\hline & Skewness & p-value & Kurtosis & p-value & Skew\&Kurt & p-value \\
\hline Jarque-Bera & & & & & & \\
\hline \multirow[t]{2}{*}{ Residual vector } & 9.668 & 0.139 & 8.415 & 0.209 & 18.083 & 0.113 \\
\hline & Stationarity & p-value & Weak exogeneity & p-value & Exclusion & p-value \\
\hline RER & 24.20 & 0.000 & 14.53 & 0.002 & 22.06 & 0.000 \\
\hline REL & 21.48 & 0.000 & 12.28 & 0.006 & 30.43 & 0.000 \\
\hline CA & 22.61 & 0.000 & 11.71 & 0.008 & 16.79 & 0.000 \\
\hline CAPITA & 28.32 & 0.000 & 6.42 & 0.093 & 10.09 & 0.017 \\
\hline TOT & 21.70 & 0.000 & 5.05 & 0.168 & 23.68 & 0.000 \\
\hline OPEN & 15.68 & 0.001 & 17.44 & 0.000 & 11.63 & 0.008 \\
\hline
\end{tabular}

Notes: as for Table 1. 
The question to be addressed here is the gap, which may persist between the path of the real exchange rate and the estimated trajectory of the equilibrium real exchange rate. In other words, it would be interesting to find out whether the real exchange rate experienced an excessive appreciation and whether it was overvalued over the past 10 years. For this purpose, we compare the observed appreciation of the real exchange rate with the estimated equilibrium real exchange rate. However, on the face of it, we could only speak about an excessive real appreciation / depreciation since all the series we use during the estimation are constructed as cumulated indexes with the year of reference of 1992 for Hungary, Poland and the Czech Republic, and of 1993 for Slovakia and Slovenia. In order to be able to conclude as to a possible over- or undervaluation in real terms, one might choose a base year when the fundamentals with a special regard to the current account could be considered as sustainable as in Edwards (1994), Elbadawi (1994), Mongardini (1998) and Filipozzi (2000). Following this approach and based on the discussion of the macroeconomic situation, we choose 1992 for Hungary, 1993 for the Czech Republic and Slovakia and 1994 for Poland and Slovenia as the benchmark year when the current account was in a sustainable position. Next, we compare these years with what had obtained Begg et al (1999) while examining the level of the equilibrium real exchange rate in a number of transition countries. In fact, our choice is roughly confirmed by the results of Begg et al (1999). Figure 2 shows the extent in \% to which the 5 countries' currency could have been over- or undervalued over the period under study.

In fact, we can distinguish between two cases. While in Hungary and Slovenia, the real exchange rate does not seem to be overvalued over the period under study, there are signs of substantial real overvaluation in the cases of the Czech Republic, Poland and Slovakia. In Hungary, although we can observe an undervaluation of up to $10 \%$ in the first half of the $1990 \mathrm{~s}$, the real exchange rate is found to converge to and to stabilise around its estimated equilibrium value. This is because of the pre-announced crawling peg system, which explicitly considered the evolution of the fundamentals when it came to determining the rate of crawl. The case of Slovenia is very similar to what we can observe in Hungary. It is possible to say that over the whole period, the Slovenian real exchange rate was very close to its equilibrium value. Once again, it is probable due to the exchange rate policy consisting in managing the nominal exchange rate the way the real exchange rate never appreciate too much. Turning to Poland, the Czech Republic and Slovakia, figure 2 shows a substantial overvaluation in all three cases at the end of the period studied. However, some major differences have to be noted. As to Poland, it is true to say that the misalignment is not too important in the early 1990s and even absent in 1994 but becomes larger from 1995 onward. Nevertheless, the misalignment vis-à-vis the equilibrium exchange rate is pretty volatile. The responsibility for the increasing and more volatile misalignment in the second half of the period studied can go to the increased volatility and appreciation of the nominal exchange rate resulting from the enlargement of the fluctuation band and then the move to free floating. Examining the case of the Czech Republic reveals a widening gap between the observed and the estimated equilibrium real exchange rate: we can observe an increasing overvaluation of the Czech currency in real terms from the beginning of the transition process. We should note that the trend overvaluation seems to be broken in 1997, date of the currency crisis: the real exchange rate moves very close to the estimated sustainable real exchange rate. But soon after that, the overvaluation reappears and is around $15 \%$ in 2001. Like in the case Poland, free floating going in tandem with a nominal appreciation of the currency in effective terms could be responsible for this. The case of Slovakia is slightly different from that of the Czech Republic and Poland. In the 
early 1990s, the real exchange rate turns out to be in the neighbourhood of its estimated sustainable value. Afterwards, it' getting overvalued in real terms and reaches the maximum of the overvaluation at about $10 \%$. Since the stabilisation programme implemented in early 1998 , the extent of the misalignment tends to be smaller and attains 7-8\% in 2001.

Figure 2. The extent of the over- and undervaluation of the real exchange rate (in \%)
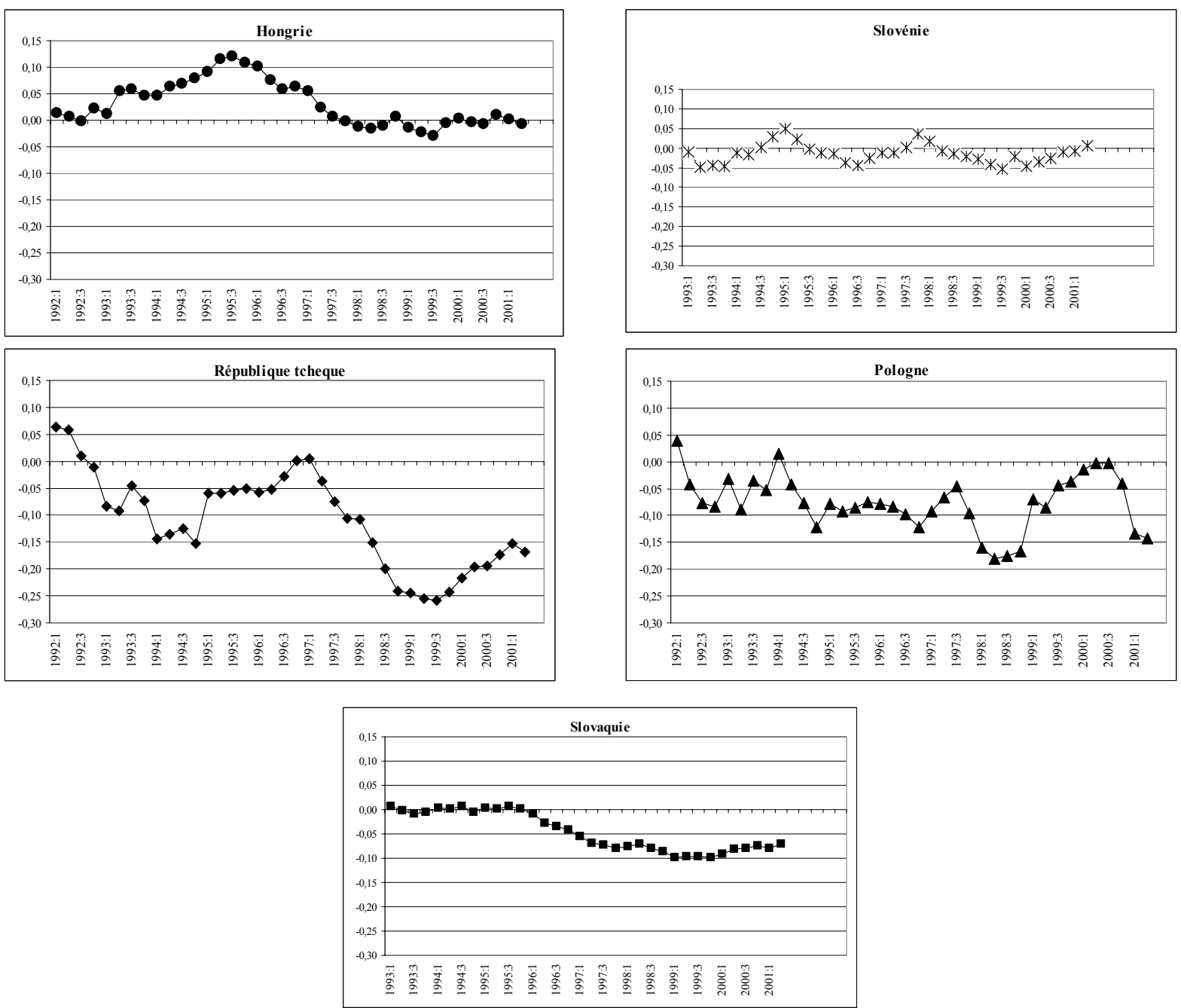

Note: minus (positive) figures mean an overvaluation (undervaluation)

\section{Conclusion}

One main feature which emerges from the analyses of the equilibrium real exchange rate is that a more flexible exchange rate regime might bring about substantial misalignments. As a matter of fact, in the first half of the 1990s, the cause behind the appreciation of the real exchange rate was mainly the inflation differential vis-à-vis the rest of the world. The nominal exchange rate was devaluated at a regular basis in 3 of the 5 countries whereas was kept unchanged in the Czech Republic and Slovakia. Nevertheless, the countries decided to liberalise capital movements because of OECD membership and as a result of the negotiation process with the EU on 
accession. Bearing in mind the incompatibility triangle which can also be referred to as the trilemma in international finance, the choice to keep the autonomy of the monetary policy led to an increased nominal exchange rate flexibility. For the time being, the Czech Republic, Poland, Slovakia and Slovenia have a free floating exchange rate regime. In Hungary, the nominal exchange rate is fluctuating in a band of $\pm 15 \%$ around the central parity. As the 5 transition economies attracted a large amount of FDI and witnessed to large short term capital inflows on account of high real interest rates, the free floating nominal exchange rate came under pressure and tended to appreciate systematically. At the same time, in spite of the positive effect of lower import prices on overall inflation caused by nominal exchange rate appreciation, the inflation differential remained still positive towards the rest of the world. The real exchange rate appreciated indeed not only because of the inflation differential but also due to an appreciating nominal exchange rate. However, this appreciation might not be appropriate in the longer term and can lead to substantial exchange rate misalignments. Given the extreme openness of the countries in terms of foreign trade, the excessive appreciation (and volatility) of the real exchange rate may penalise exports and thus have a negative impact on overall economic performance. As there is no possibility to suspend the freedom of capital movements and thus to return to fixed exchange rate regimes, the only feasible alternative to eliminate nominal exchange rate appreciation and volatility is a rapid entry into EMU. However, it is easier said than done. In fact, three questions need to be answered. The first one concerns the determination of the nominal parity at which the currencies will be irrevocably pegged to the euro. Second, all necessary structural reforms need to be effectively implemented by the time of entry so that accession to EMU should not turn out something like building a bridge of ice in the summer. Third, should the candidate countries reach a certain level of economic development, say the average per capita GDP of the EMU? We believe that despite of these questions, early entry into EMU should be possible. Though, it must be emphasised that in accordance with the trilemma, the independence of monetary policy is to be sacrificed on the altar of exchange rate stability. In exchange for this, not only all the benefits of the introduction of the euro, that is the absence of conversion costs, of exchange rate risk and thus lower interest rate through lower risk premium, more stable macroeconomic environment, will be available but the real exchange rate is to appreciate in function of the inflation differential. In the case of sound macroeconomic policy, the resulting real appreciation might be sustainable in the long run. 


\section{William Davidson Institute Working Paper 480}

\section{References}

Alberola, Enrique - Cervero, Susana G. - Lopez, Humberto - Ubide, Angel (1999): Global Equilibrium Exchange Rates: Euro, Dollar, "Ins", "Outs" and Other Major Currencies in a Panel Co-integration Framework, IMF Working Paper No. 175, December, Washington D.C.

Avallone, Nathalie - Lahrèche-Révil, Amina (1999) : Le taux de change réel d'équilibre dans les pays en transition : le cas de la Hongrie, TEAM, University of Paris 1, Cahiers blancs 1999/91, http://mse.univ-paris1.fr/MSEPageCahierSBla.htm

Baffes, J., Elbadawi, I. - O’Connell, S. (1997) : Single Equation of the Equilibrium Real Exchange Rate, in L. Hinkle - P. Montiel (eds.), Estimating Equilibrium Exchange Rates in Developing Countries, Washington D.C.: The World Bank and World Bank Working Paper No. 08/20/97

Baffes, John, Elbadawi, Ibrahim A - O'Connell, Stephen A. (1999) : Single Equation of the Equilibrium Real Exchange Rate, in L. Hinkle - P. Montiel (eds.), Estimating Equilibrium Exchange Rates in Developing Countries, Washington D.C.: The World Bank

Bayoumi, Tamim - Clark, Peter - Symansky, Steve - Taylor, Mark (1994): The Robustness of Equilibrium Exchange rate Calculations of Alternative Assumptions and Methodologies, in John Williamson (ed.), Estimating Equilibrium Exchange Rates, Institute for International Economics, Washington D.C., pp. 19-60

Begg, David - Halpern, László and Charles Wyplosz, 1999, Monetary and Exchange Rate Policies, EMU and Central and Eastern Europe, Forum Report on the Economic Policy Initiative No. 5, CEPR: London, EastWest Institute: New York, Prague

Borowski, Didier - Couharde, Cécile - Thibault, Florence (1998a): Les taux de change d'équilibre fondamentaux: de l'approche théorique à l'évaluation empirique, Revue française d'économie, vol 13, n³, été, pp. 177-206.

Borowski, Didier - Couharde, Cécile - Thibault, Florence (1998b): Les Sensibilités des taux de change d'équilibre aux output gaps et aux cibles courante, Economie et Prévision, $\mathrm{n}^{\circ} 134,3^{\mathrm{e}}$ trimestre, pp. 71-96

Borowski, Didier - Couharde, Cécile (1999): Quelle parité d'équilibre pour l'euro, Economie Internationale, 77, $1^{\mathrm{er}}$ trimestre, pp. $21-44$

Borowski, Didier - Couharde, Cécile (2000a): Euro, dollar, yen: Pour une approche multilatérale des taux de change d'équilibre, Revue économique, Vol. 51, No. 3., mai, pp. 671-681.

Borowski, Didier - Couharde, Cécile (2000b): The exchange rate macroeconomic balance approach: new methodology and results for the euro, the dollar, the yen and the pound sterling, papier présenté au colloque "Reshaping the Architecture of the International Financial System “, May 23-24, 2000, Siena, Italy

Clark, Peter B. - MacDonald, Ronald (1998): Exchange Rates and Economic Fundamentals: A Methodological Comparison of BEERs and FEERs, IMF Working Paper No. 67, May, Washington D.C.

Clark, Peter B. - MacDonald, Ronald (2000) : Filtering the BEER - A Permanent and Transitory Decomposition, IMF Working Paper No. 144, August, Washington D.C.

Clark, Peter B. - McDonald, Ronald (1998): Exchange Rates and Economic Fundamentals: A Methodological Comparison of BEERs and FEERs, IMF Working Paper No. 67, May, Washington D.C.

Clostermann, J. and B. Schnatz (2000) : The Determinants of the Euro-Dollar Exchange Rate: Synthetic Fundamentals and a Non-Existing Currency, Deutsche Bundesbank, Discussion Paper No.2.

Coricelli, Fabrizio - Jazbec, Bostjan (2001): Real Exchange Rate Dynamics in Transition Economies, Centre for Economic Policy Research, Discussion Papers Series No. 2869, July

Coudert, Virginie (1999): Comment définir un taux de change d'équilibre pour les pays émergents ? Economie Internationale, No. $77,1^{\text {er }}$ trimester, pp. 45-65.

Couharde, Cécile - Mazier, J. (2000): La détermination des taux de change d'équilibre fondamentaux: une approche simplifiée, Economie appliquée, tome LIII, $\mathrm{n}^{\circ} 3$, pp. 59-86.

De Broeck, Mark - Sløk, Torsten (2001): Interpreting Real Exchange Rate Movements in Transition Countries, IMF Working Paper No. 56, May, Washington D.C. 


\section{William Davidson Institute Working Paper 480}

Edwards, Sebastian (1994): Real and Monetary Determinants of Real Exchange Rate Behavior: Theory and Evidence from Developing Countries, in John Williamson (ed.), Estimating Equilibrium Exchange Rates, Institute for International Economics, Washington D.C., pp. 61-92

Elbadawi, Ibrahim A. (1994): Estimating Long-Run Equilibrium Real Exchange Rates, in Estimating Equilibrium Exchange Rates, in John Williamson (ed.), Estimating Equilibrium Exchange Rates, Institute for International Economics, Washington D.C., pp. 93-132

Feyzioglu, Tarhan (1997): Estimating the Equilibrium Real Exchange Rate: An Application to Finland, IMF Working Paper No. 109, September, Washington D.C.

Filipozzi, Fabio (2000): Equilibrium exchange rate of the Estonian kroon, its dynamics and its impacts of deviations, Bank of Estonia, Working Paper No. 2

Frait, Jan - Komárek, Lubosek (1999): Dlouhodobý rovnovážný re álný měnový kurz koruny a jeho determinanty, Czech National Bank, Monetary Policy Division Working Paper no. 9.

Halpern, László - Wyplosz, Charles (1997): Equilibrium Exchange Rates in Transition Countries, IMF Staff Papers, Vol. 44, No. 4, December, pp. 430-461., Washington D.C.

International Monetary Fund (1998): Republic of Slovakia: Recent Economic Developments, IMF Staff Country Report No. 98/60, Washington D.C., pp. 41-47.

Johansen, Søren (1996): Likelihood-based Inference in Cointegrated Vector Auto-Regressive Models, Oxford, United Kingdom: Oxford University Press

Joly, Hervé - Prigent, Céline - Quinet, Alain. - Sobczak, Nicolas (1999): Une estimation du taux de change réel d'équilibre pour l'économie française, Economie Internationale, $\mathrm{n}^{\circ} 77,1^{\text {er }}$ trimestre, pp. 3-20.

Krajnyák, Kornélia - Zettelmeyer, Jeromin (1998): Competitiveness in Transition Economies: What Scope for Real Appreciation? IMF Staff Papers No. 45, June, pp. 309-62., Washington D.C.

Lim, Guay-Cheng (2000): Misalingment and Managed Exchange Rates: An Application to the Thai Baht, IMF Working Paper No. 63, Washington D.C.

Maeso-Fernandez, Francisco - Osbat, Chiara - Schnatz, Bernd (2001) : Determinants of the euro real effective exchange rate : A BEER/PEER approach, ECB Working Paper No. 85, November, Frankfurt

Maurin Laurent (2001): Fundamental determinants of RER for transition countries, in Michael H. Stierle and Thomas Birringer (eds.): Economics of Transition: Theory, Experiences and EU-Enlargement, Verlag für Wissenschaft und Forschung, pp. 427-442.

Maurin, Laurent (2000): La modélisation des taux de change d'équilibre et leur estimation pour l'euro, le dollar et le yen, Economie et Prévision, No. 142, pp. 1-11.

Mongardini, Joannes (1998): Estimating Egypt's Equilibrium Real Exchange Rate, IMF Working Paper No. 5, January, Washington D.C.

Montiel Peter J. (1999): Determinants of the long-run equilibrium real exchange rate: an analytical model in Hinkle Lawrence. E., Montiel Peter J. 1999: Exchange rate misalignment: concepts and measurement for developing countries, World Bank, Oxford Press University, New York

Paiva, Claudio (2001): Competitiveness and the Equilibrium Exchange Rate in Costa Rica, IMF Working Paper No. 23, Washington D.C.

Rother, C. Ph., 2000, The Impact of Productivity Differentials on Inflation and the Real Exchange Rate: An Estimation of the Balassa-Samuelson Effect in Slovenia, IMF Country Report, Republic of Slovenia: Selected Issues, No. 56, 26-39

Šmídková, Katerina (1998): Estimating the FEER for the Czech Economy, Czech National Bank, Institute of Economy Working PaperSeries No. 87, Prague

Stein, Jerome L. (1994): The Natural Real Exchange Rate of the US dollar and Determinants of Capital Flows, in Estimating Equilibrium Exchange Rates in John Williamson (ed.), Estimating Equilibrium Exchange Rates, Institute for International Economics, Washington D.C., pp. 133-176 


\section{William Davidson Institute Working Paper 480}

Sundarajan, V. - Lazare, Michel - Sherwyn, Williams (1999): Exchange Rate Unification, the Equilibrium Real Exchange Rate and Choice of Exchange Rate Regime: The Case of the Islamic Republic of Iran, IMF Working Paper No. 15, January, Washington D.C.

Williamson, John (1994): Estimates of FEERs in John Williamson (ed.), Estimating Equilibrium Exchange Rates, Institute for International

Economics,
Washington
D.C.,

pp.

177-244 
William Davidson Institute Working Paper 480

\section{APPENDIX: Stability tests on the cointegration rank and the estimated coefficients}

\section{Czech Republic}
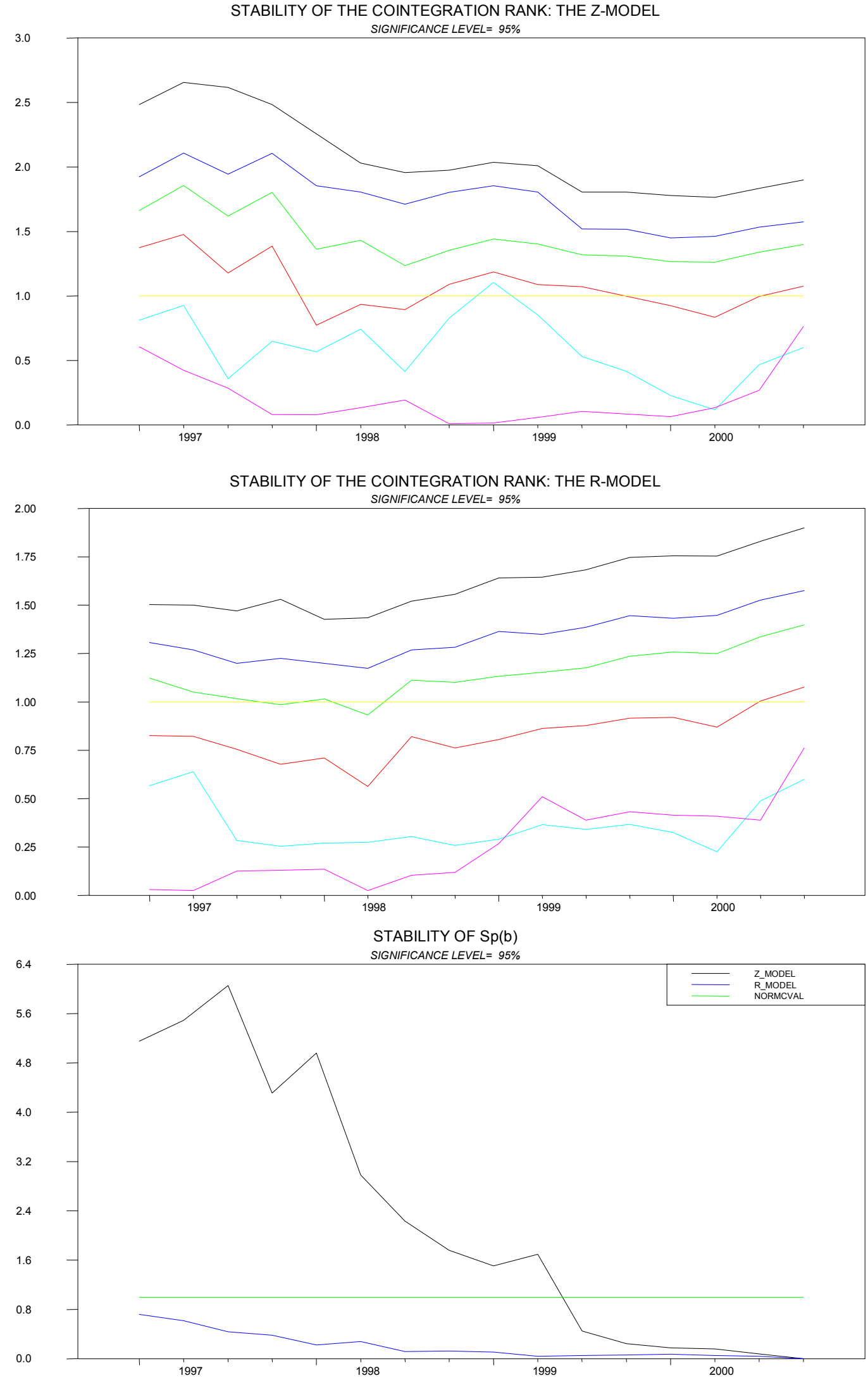
William Davidson Institute Working Paper 480

\section{Hungary}

STABILITY OF THE COINTEGRATION RANK: THE R-MODEL

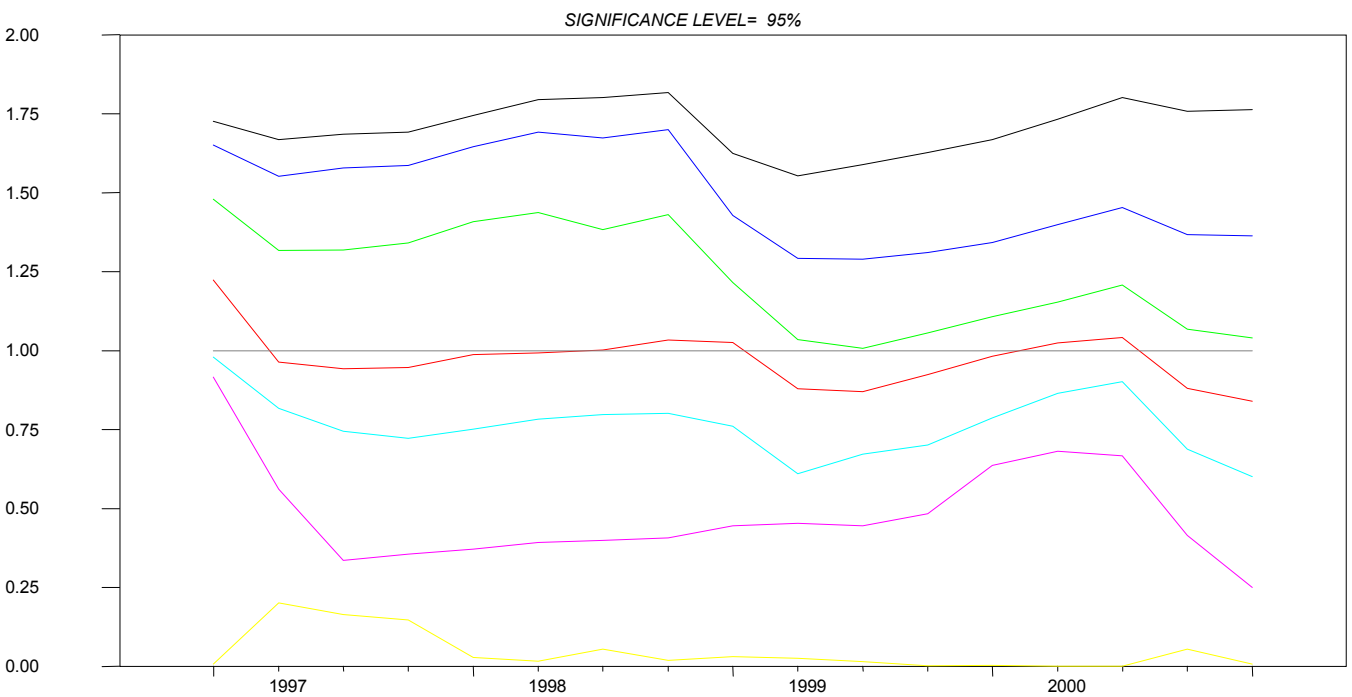

STABILITY OF THE COINTEGRATION RANK: THE Z-MODEL

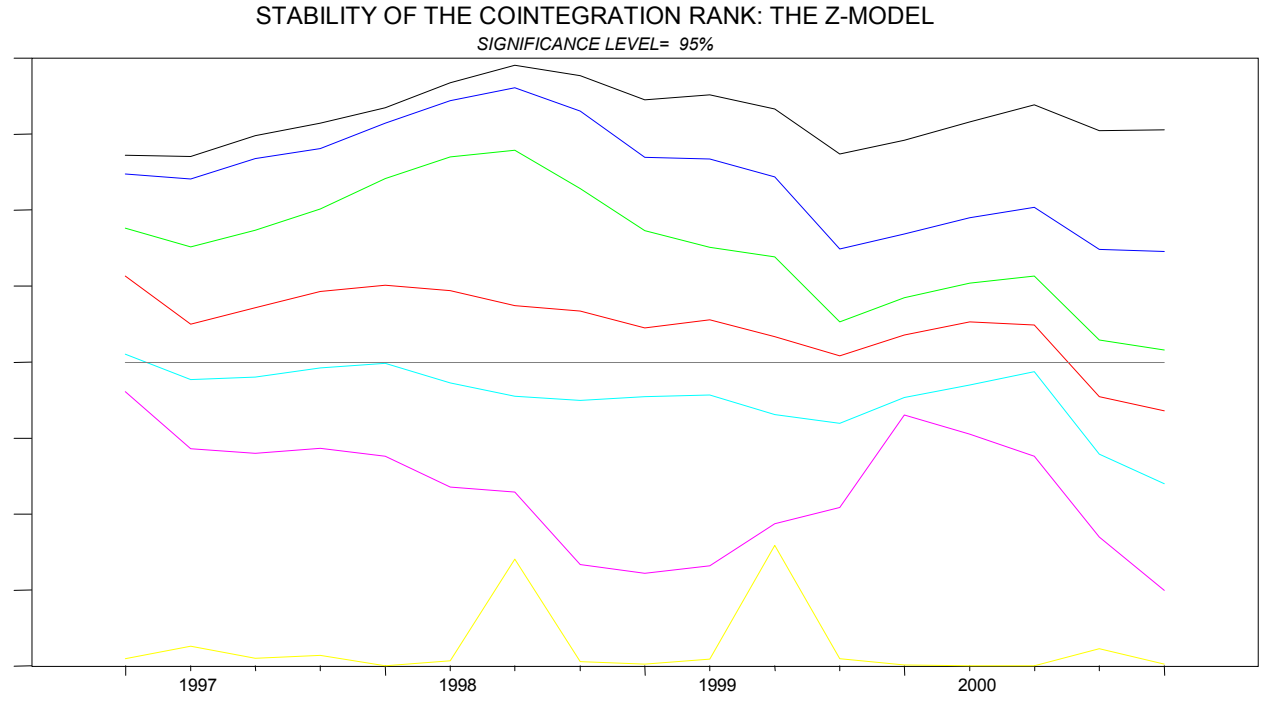

3.0

STABILITY OF Sp(b)

SIGNIFICANCE LEVEL $=95 \%$

2.5

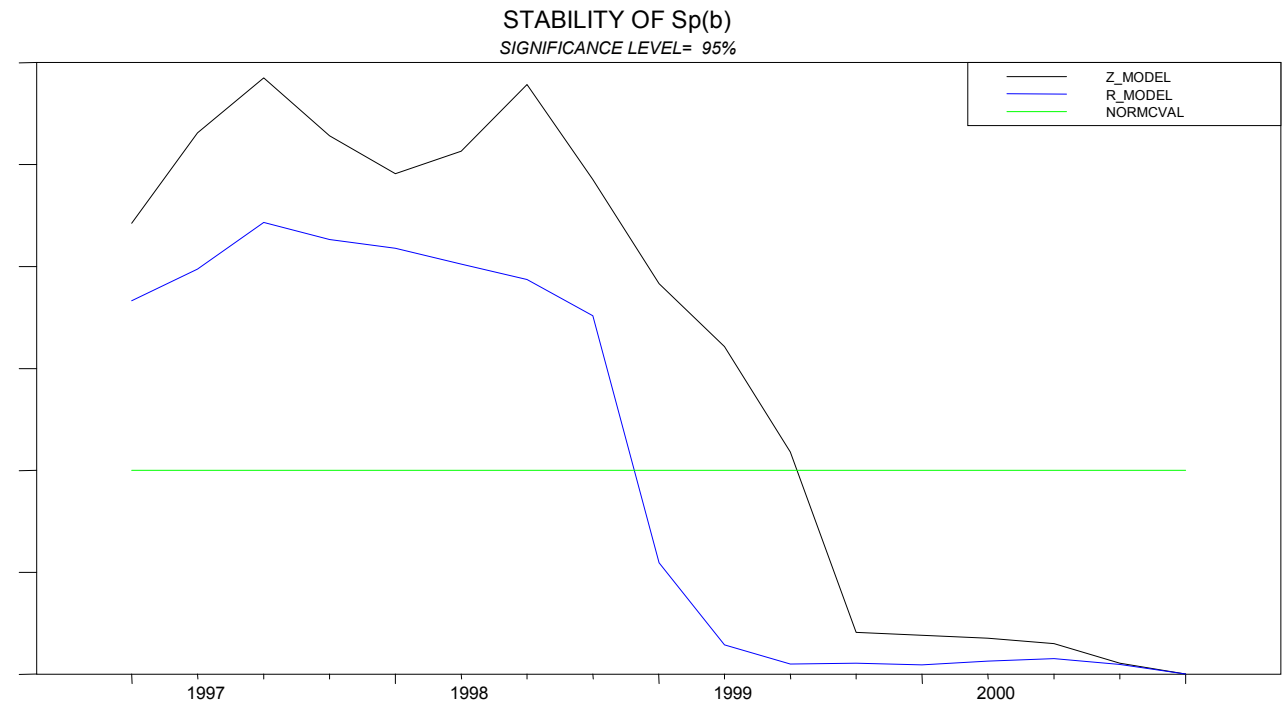


William Davidson Institute Working Paper 480

\section{Poland}

3.0

1.5

1.0

0.5

0.0

3.0

2.0

1.5

1.0

0.5

3.5

3.0

2.5

2.0

1.5

1.0

0.0

5

STABILITY OF THE COINTEGRATION RANK: THE R-MODEL

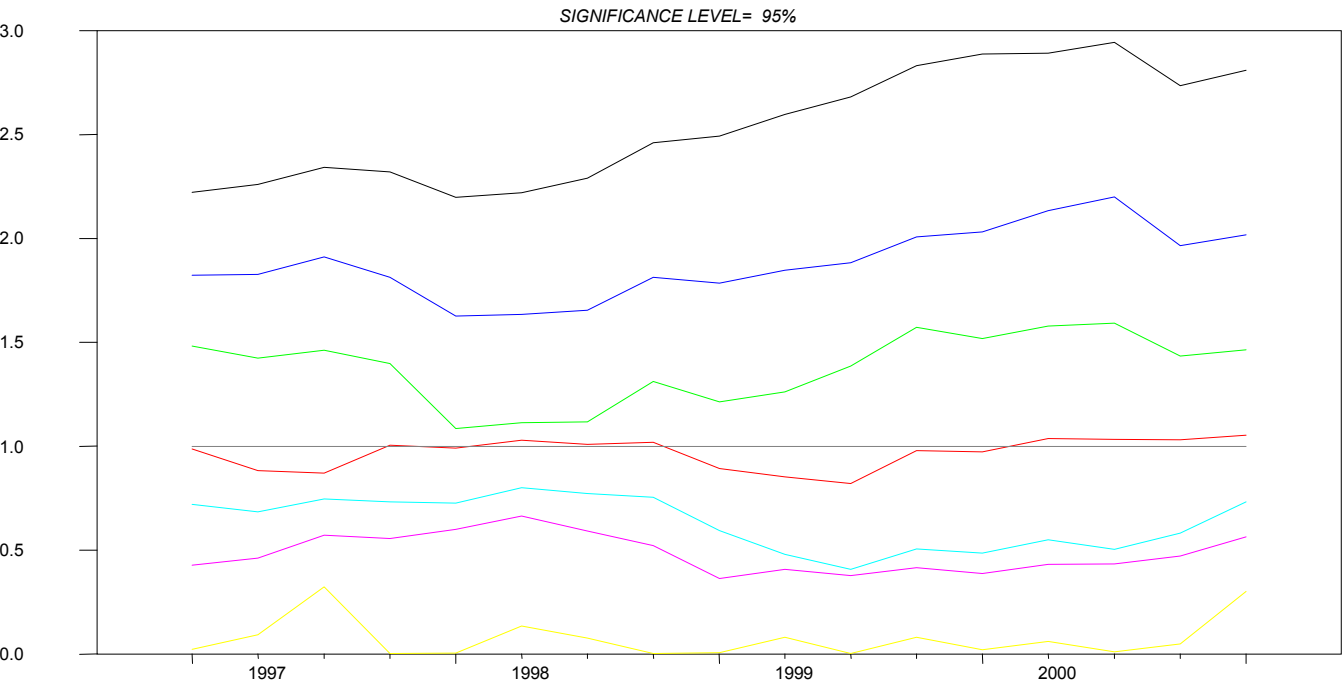

STABILITY OF THE COINTEGRATION RANK: THE Z-MODEL

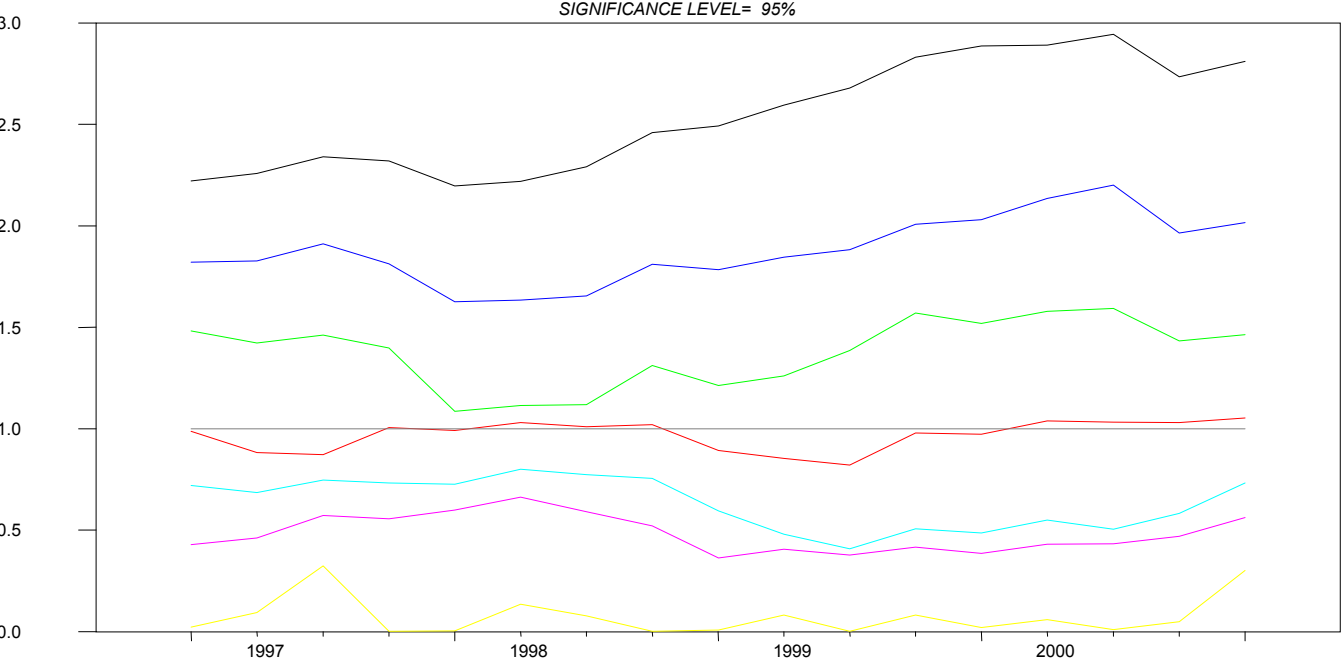

STABILITY OF $\mathrm{Sp}(\mathrm{b})$

SIGNIFICANCE LEVEL $=95 \%$

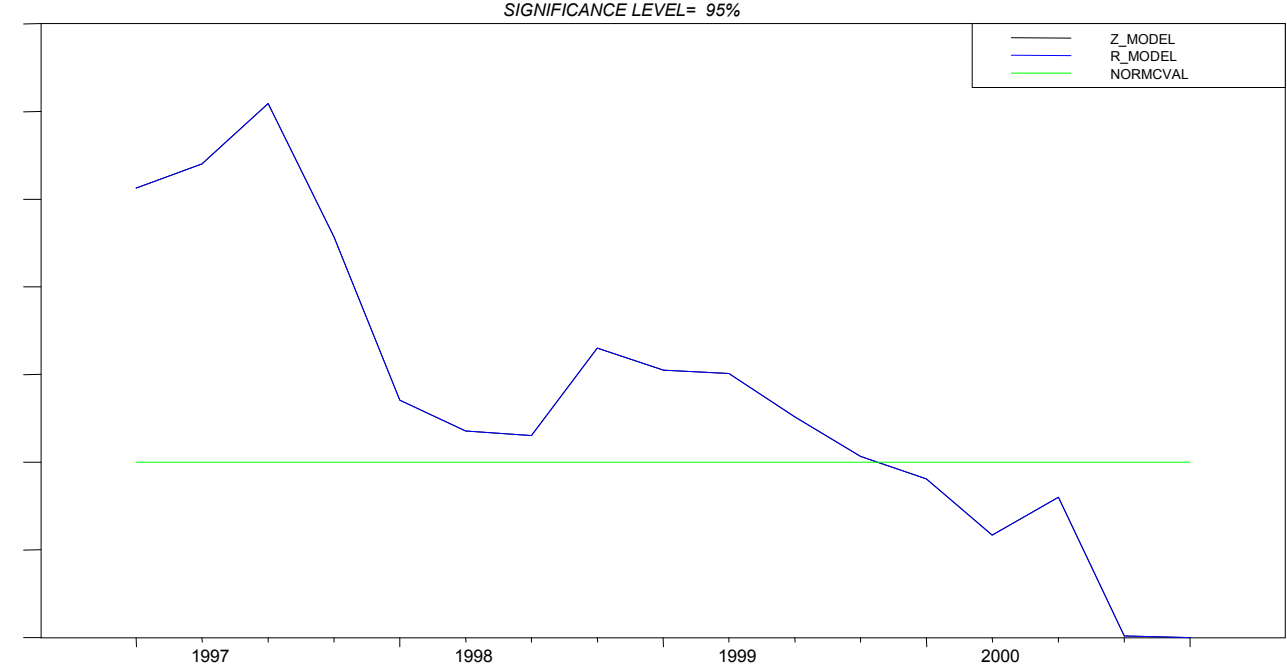


William Davidson Institute Working Paper 480

\section{Slovakia}

STABILITY OF THE COINTEGRATION RANK: THE R-MODEL SIGNIFICANCE LEVEL $=95 \%$

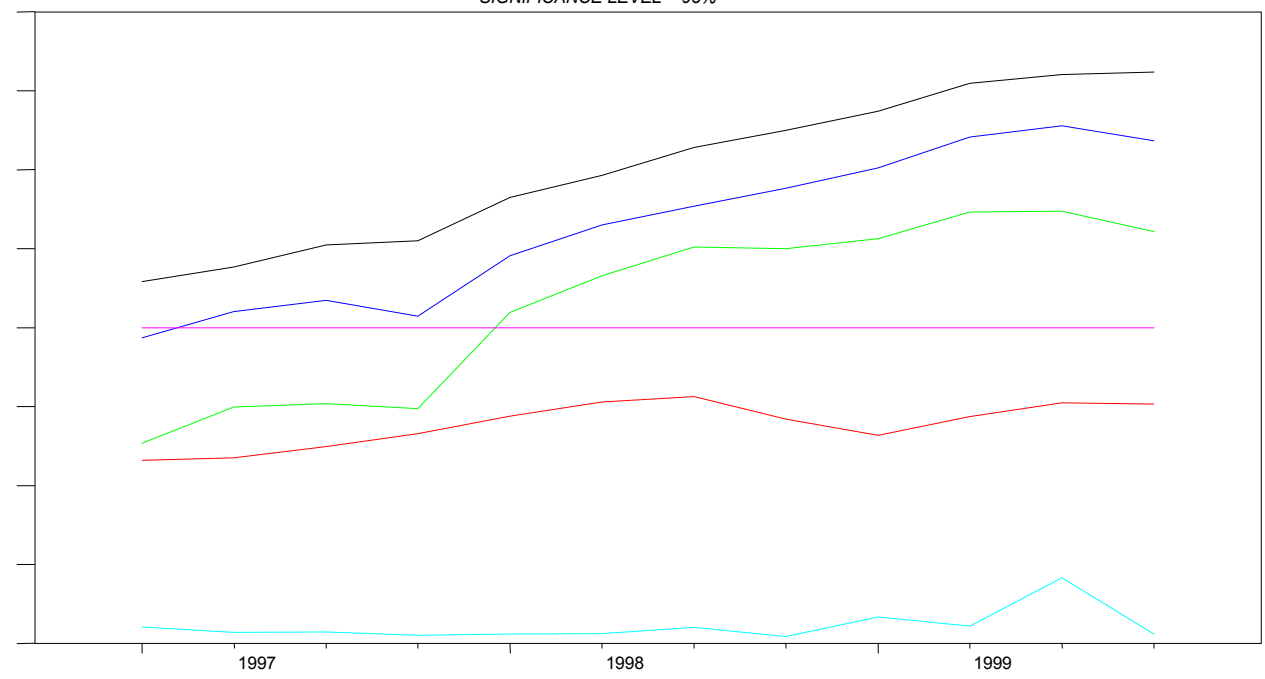

STABILITY OF THE COINTEGRATION RANK: THE Z-MODEL

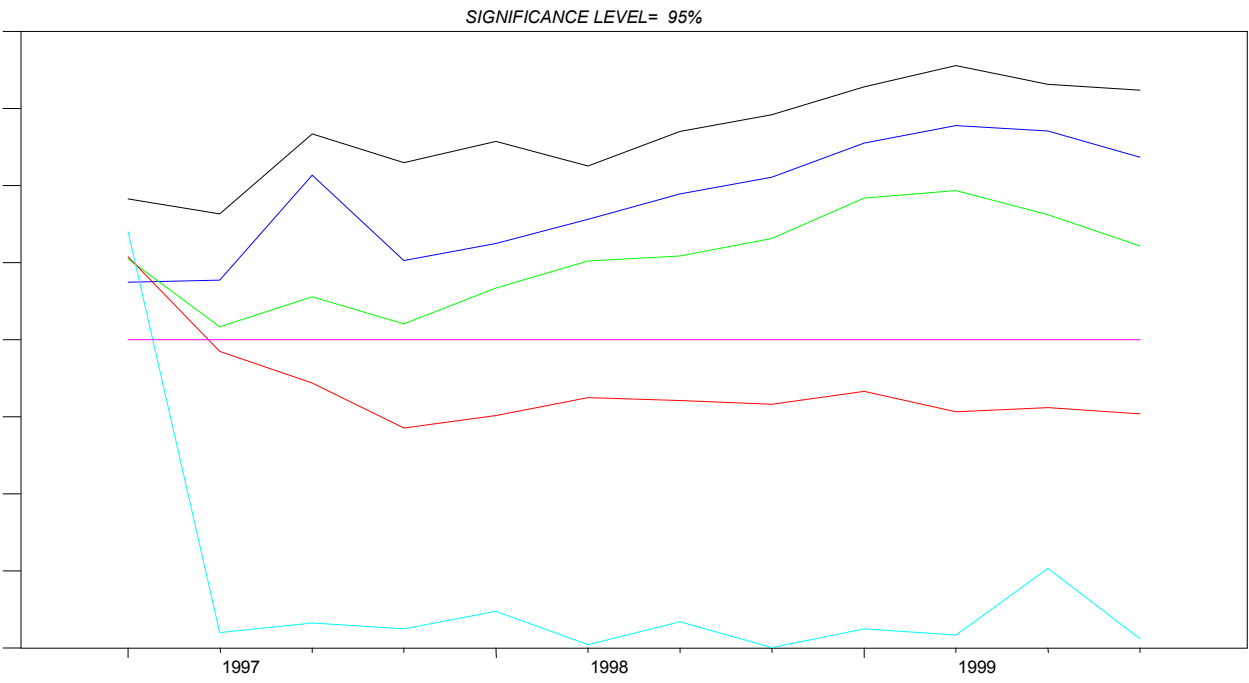

25

STABILITY OF Sp(b)

2.25

2.00

1.75

1.50

1.25

1.00

0.75

0.50

0.25

0.00

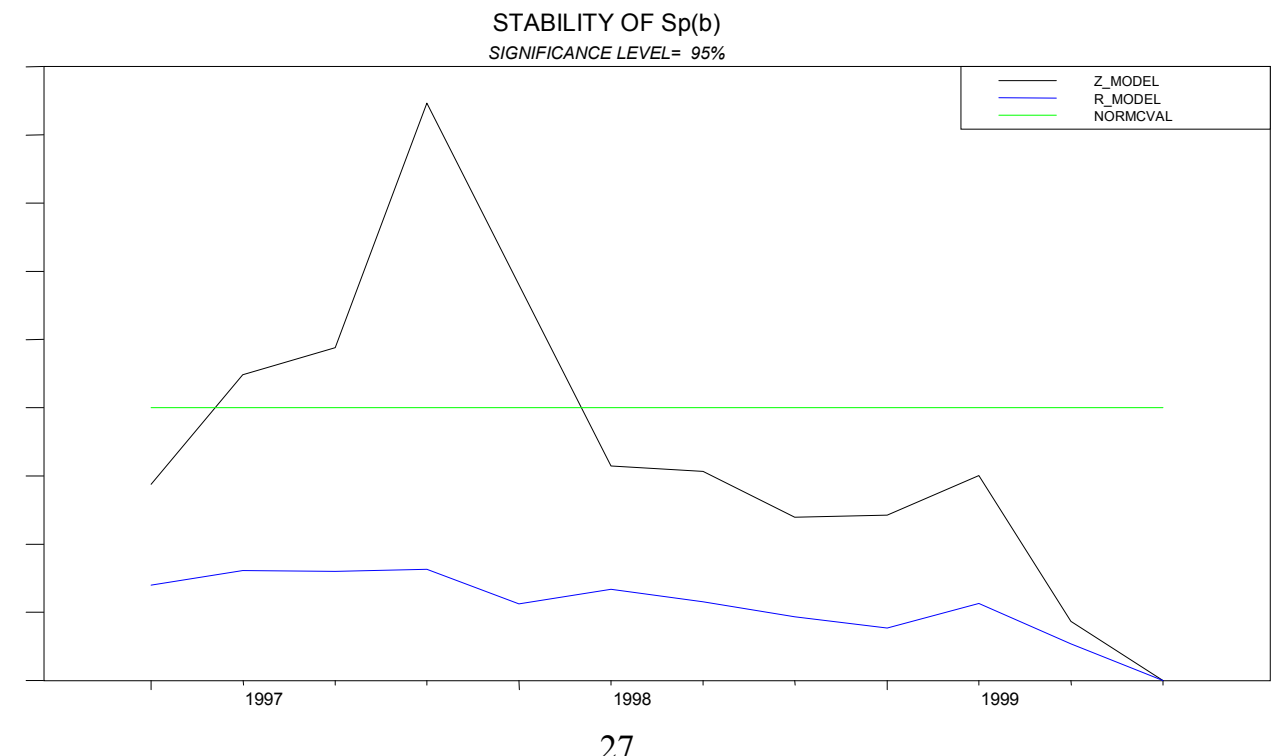


William Davidson Institute Working Paper 480

\section{Slovenia}

STABILITY OF THE COINTEGRATION RANK: THE R-MODEL

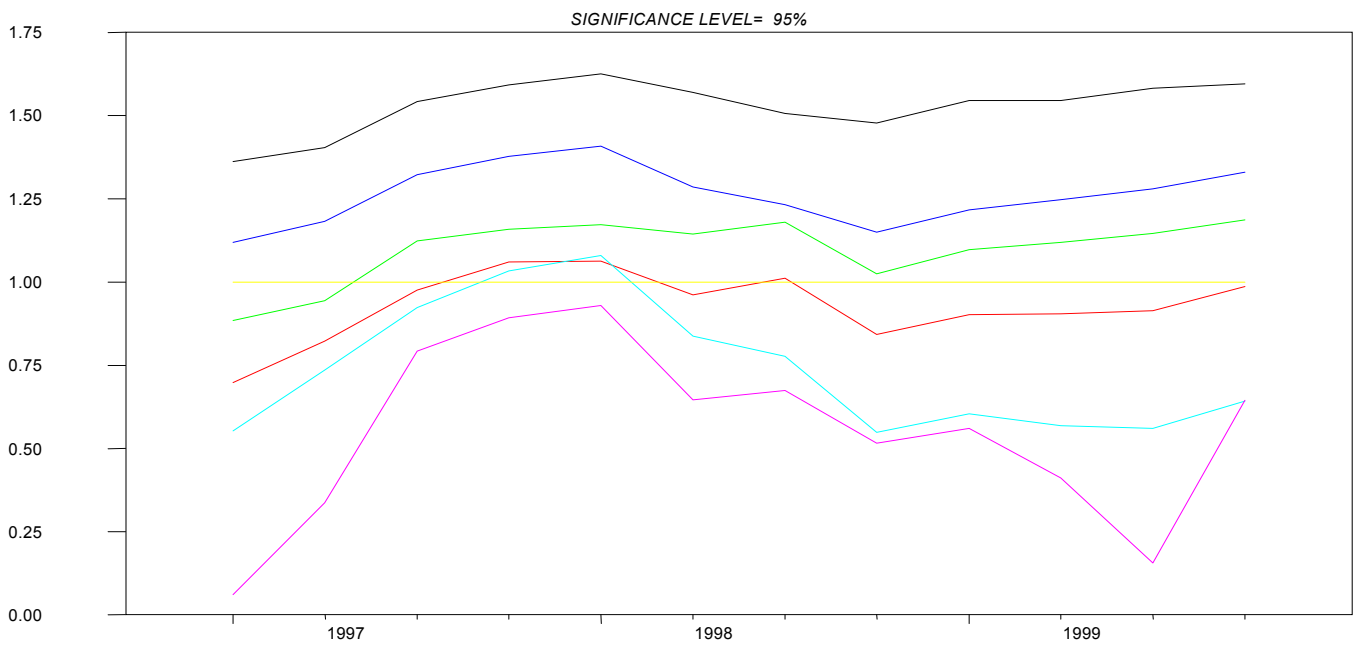

STABILITY OF THE COINTEGRATION RANK: THE Z-MODEL

2.25 SIGNIFICANCE LEVEL $=95 \%$

2.00

1.75

1.50

1.25

1.00

0.75

0.50

0.25

0.00

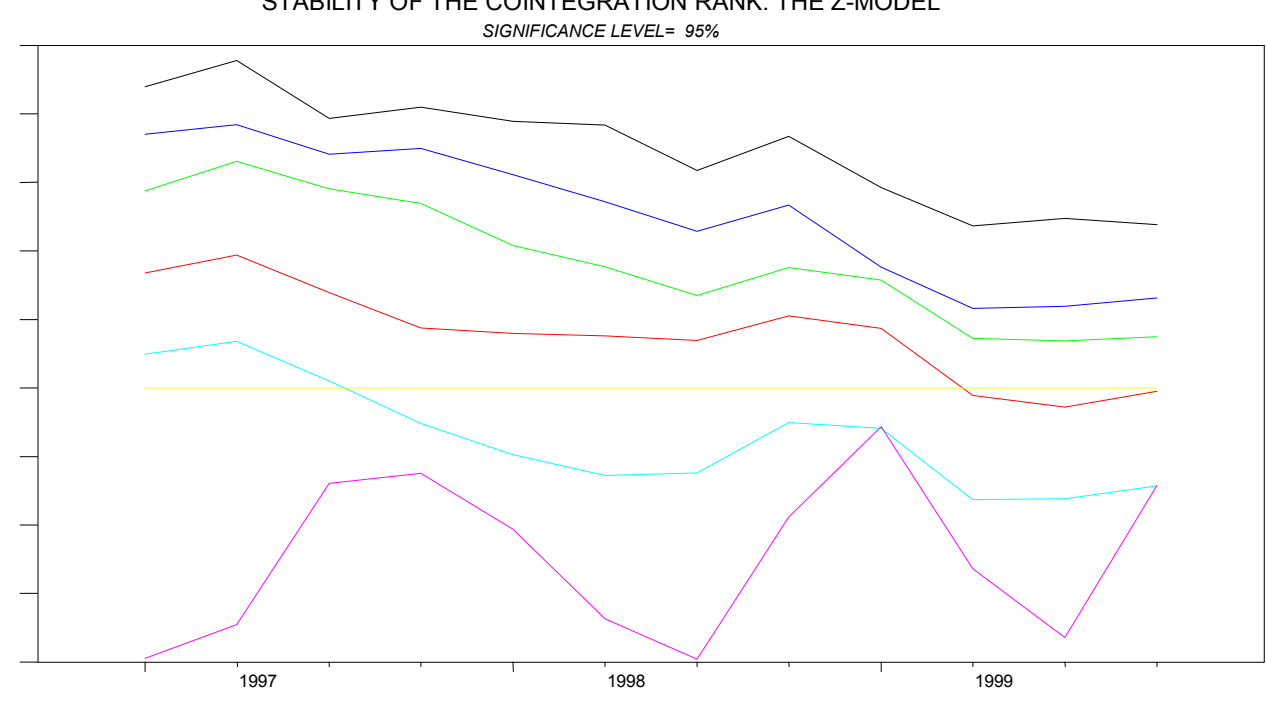

3.0

STABILITY OF Sp(b)

3.0

2.5

2.0

1.5

1.0

0.0

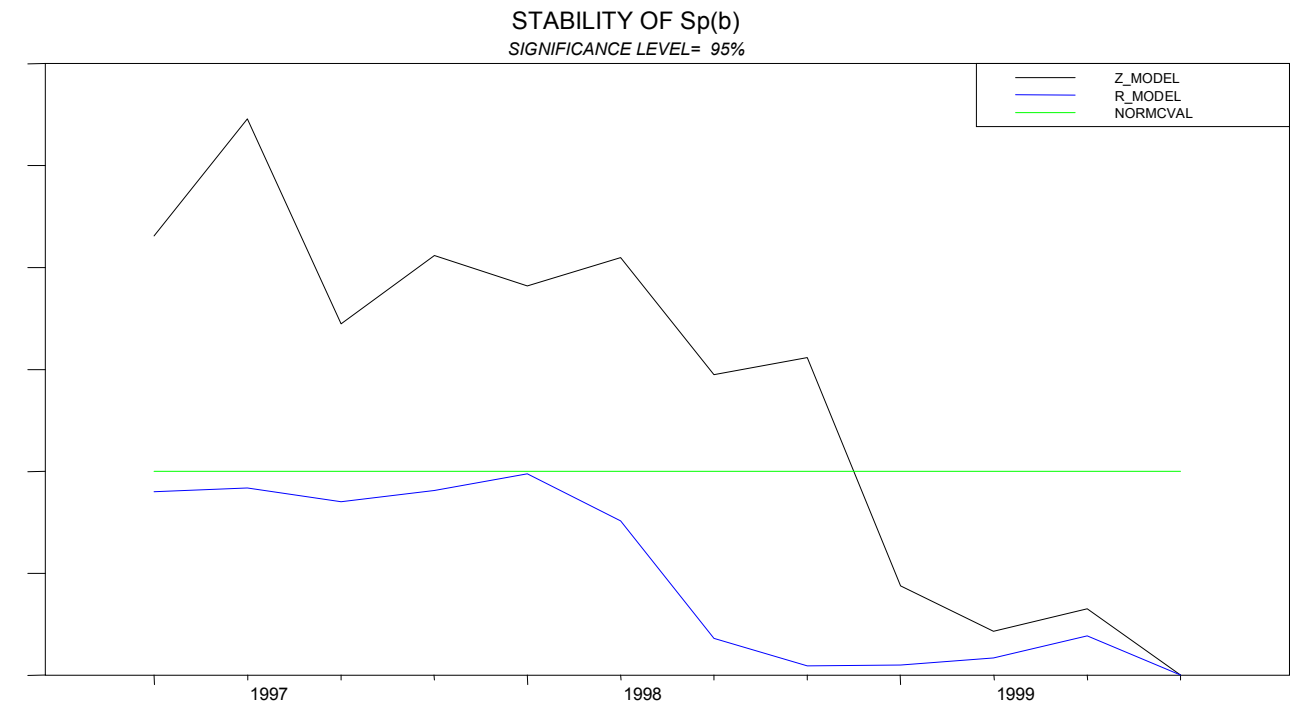




\section{DAVIDSON INSTITUTE WORKING PAPER SERIES - Most Recent Papers}

The entire Working Paper Series may be downloaded free of charge at: www.wdi.bus.umich.edu

CURRENT AS OF 7/10/02

\begin{tabular}{|c|c|c|}
\hline Publication & Authors & Date \\
\hline $\begin{array}{l}\text { No. 480: Equilibrium Real Exchange Rates in Central Europe's } \\
\text { Transition Economies : Knocking on Heaven's Door }\end{array}$ & Balázs Égert & July 2002 \\
\hline $\begin{array}{l}\text { No. 479: The Impact of Minimum Wages on Wage Inequality and } \\
\text { Employment in the Formal and Informal Sector in Costa Rica }\end{array}$ & $\begin{array}{l}\text { Fatma El-Hamidi and Katherine } \\
\text { Terrell }\end{array}$ & Apr. 2001 \\
\hline $\begin{array}{l}\text { No. 478: Beyond Oaxaca -Blinder: Accounting for Differences in } \\
\text { Household Income Distributions }\end{array}$ & $\begin{array}{l}\text { François Bourguignon, Francisco } \\
\text { H. G. Ferreira and Phillippe G. } \\
\text { Leite }\end{array}$ & Feb. 2002 \\
\hline $\begin{array}{l}\text { No. 477: Participation Behavior of East German Women after German } \\
\text { Unification }\end{array}$ & Holger Bonin and Rob Euwals & July 2002 \\
\hline No. 476: Duration and Risk of Unemployment in Argentina & $\begin{array}{l}\text { Sebastian Galiani and Hugo A. } \\
\text { Hopenhayn }\end{array}$ & Oct. 2001 \\
\hline $\begin{array}{l}\text { No. 475: After, Before and During: Returns to Education in the } \\
\text { Hungarian Transition }\end{array}$ & $\begin{array}{l}\text { Nauro F. Campos and Dean } \\
\text { Jolliffe }\end{array}$ & Apr. 2002 \\
\hline No. 474: The Locking-in Effect of Subsidized Jobs & Jan C. van Ours & June 2002 \\
\hline No. 473: How Reform Worked in China & Yingyi Qian & June 2002 \\
\hline No. 472: An Economic Perspective on Russia's Accession to the WTO & Robert M. Stern & June2002 \\
\hline $\begin{array}{l}\text { No. 471: The Effects of Ownership Forms and Concentration on Firm } \\
\text { Performance after Large-Scale Privatization }\end{array}$ & Evzen Kocenda and Jan Svejnar & May 2002 \\
\hline $\begin{array}{l}\text { No. 470: Growth in Transition: What We Know, What We Don't, and } \\
\text { What We Should }\end{array}$ & $\begin{array}{l}\text { Nauro F. Campos and Fabrizio } \\
\text { Coricelli }\end{array}$ & Feb. 2002 \\
\hline $\begin{array}{l}\text { No. 469: Barriers to Investment by Russian Firms: Property Protection } \\
\text { or Credit Constraints? }\end{array}$ & Susan J. Linz & May 2002 \\
\hline No. 468: Job Satisfaction Among Russian Workers & Susan J. Linz & May 2002 \\
\hline $\begin{array}{l}\text { No. 467: Assessing the Problem of Human Capital Mismatch in } \\
\text { Transition Economies }\end{array}$ & $\begin{array}{l}\text { Viliam Druska, Byeong ju Jeong, } \\
\text { Michal Kejak, and Viatcheslav } \\
\text { Vinogradov }\end{array}$ & Mar. 2002 \\
\hline $\begin{array}{l}\text { No. 466: Motivating Russian Workers: Analysis of Age and Gender } \\
\text { Differences }\end{array}$ & Susan J. Linz & Feb. 2002 \\
\hline No. 465: Virtual Reality: Barter and Restructuring in Russian Industry & Gary Krueger and Susan J. Linz & Apr. 2001 \\
\hline $\begin{array}{l}\text { No. 464: Lending of Last Resort, Moral Hazard and Twin Crises: } \\
\text { Lessons from the Bulgarian Financial Crisis 1996/1997 }\end{array}$ & $\begin{array}{l}\text { Michael Berlemann, Kalin } \\
\text { Hristov and Nikolay Nenovsky }\end{array}$ & May 2002 \\
\hline $\begin{array}{l}\text { No. 463: Deindustrialisation. Lessons from the Structural Outcomes of } \\
\text { Post-Communist Transition }\end{array}$ & $\begin{array}{l}\text { Tomasz Mickiewicz and Anna } \\
\text { Zalewska }\end{array}$ & Jan. 2002 \\
\hline $\begin{array}{l}\text { No. 462: Joint Liability Lending and the Rise and Fall of China's } \\
\text { Township and Village Enterprises }\end{array}$ & Albert Park and Minggao Shen & July 2001 \\
\hline $\begin{array}{l}\text { No. 461: A Refinancing Model of Decentralization with Empirical } \\
\text { Evidence from China }\end{array}$ & Albert Park and Minggao Shen & Apr. 2002 \\
\hline $\begin{array}{l}\text { No. 460: The Effects of Market Liberalization on the Relative Earnings } \\
\text { of Chinese Women }\end{array}$ & $\begin{array}{l}\text { Margaret Maurer-Fazio and } \\
\text { James Hughes }\end{array}$ & Mar. 2002 \\
\hline $\begin{array}{l}\text { No. 459: The Role of Education in Determining Labor Market } \\
\text { Outcomes in Urban China's Transitional Labor Markets }\end{array}$ & Margaret Maurer-Fazio & Apr. 2002 \\
\hline $\begin{array}{l}\text { No. 458: Real and Monetary Convergence within the European Union } \\
\text { and Between the European Union and Candidate Countries: } \\
\text { A Rolling Cointegration Approach }\end{array}$ & $\begin{array}{l}\text { Josef C. Brada, Ali M. Kutan and } \\
\text { Su Zhou }\end{array}$ & Apr. 2002 \\
\hline No. 457: Credit Ratings as Coordination Mechanisms & $\begin{array}{l}\text { Arnoud W. A. Boot and Todd T. } \\
\text { Milbourn }\end{array}$ & Mar. 2002 \\
\hline $\begin{array}{l}\text { No. 456: Balkan and Mediterranean Candidates for European Union } \\
\text { Membership: The Convergence of their Monetary Policy with that of the } \\
\text { European Central Bank }\end{array}$ & Josef C. Brada and Ali M. Kutan & Apr. 2002 \\
\hline $\begin{array}{l}\text { No. 455: Russian Financial Transition: The Development of Institutions } \\
\text { and Markets for Growth }\end{array}$ & David M. Kemme & Oct. 2001 \\
\hline
\end{tabular}

